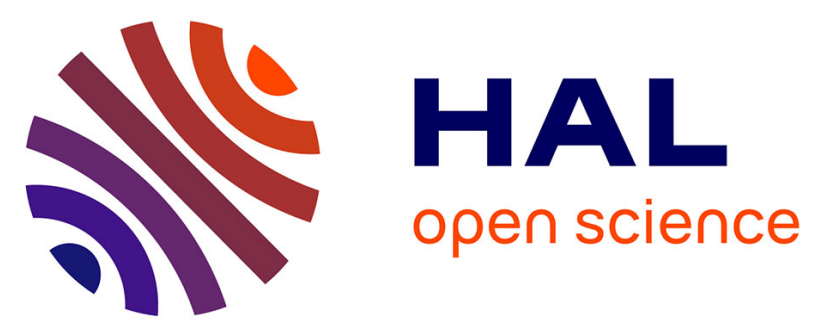

\title{
Seismic layer 2A variations in the Lucky Strike segment at the Mid-Atlantic Ridge from reflection measurements
}

Tim Seher, Wayne C. Crawford, Satish Singh, Mathilde Cannat

\section{To cite this version:}

Tim Seher, Wayne C. Crawford, Satish Singh, Mathilde Cannat. Seismic layer 2A variations in the Lucky Strike segment at the Mid-Atlantic Ridge from reflection measurements. Journal of Geophysical Research, 2010, 115 (B7), pp.B07107. 10.1029/2009JB006783 . insu-01830063

\section{HAL Id: insu-01830063 \\ https://hal-insu.archives-ouvertes.fr/insu-01830063}

Submitted on 4 Jul 2018

HAL is a multi-disciplinary open access archive for the deposit and dissemination of scientific research documents, whether they are published or not. The documents may come from teaching and research institutions in France or abroad, or from public or private research centers.
L'archive ouverte pluridisciplinaire HAL, est destinée au dépôt et à la diffusion de documents scientifiques de niveau recherche, publiés ou non, émanant des établissements d'enseignement et de recherche français ou étrangers, des laboratoires publics ou privés. 


\title{
Seismic layer 2A variations in the Lucky Strike segment at the Mid-Atlantic Ridge from reflection measurements
}

\author{
Tim Seher, ${ }^{1,2}$ Wayne C. Crawford, ${ }^{1}$ Satish C. Singh, ${ }^{1}$ and Mathilde Cannat ${ }^{1}$
}

Received 13 July 2009; revised 23 February 2010; accepted 3 March 2010; published 24 July 2010.

[1] The SISMOMAR experiment carried out seismic measurements of the slow spreading Lucky Strike segment of the Mid-Atlantic Ridge, located approximately $300 \mathrm{~km}$ south of the Azores platform. We present results from a segment scale reflection study of seismic layer 2A that is centered on the Lucky Strike volcano and covers the central $54 \mathrm{~km}$ of the $70 \mathrm{~km}$ long segment and extends $30 \mathrm{~km}$ on both sides of the ridge axis. Our study allows new conclusions about the role of tectonic, magmatic and hydrothermal processes in shaping the upper crustal structure of the Lucky Strike segment. The seismic reflection measurements show an almost constant layer 2A two-way time within the median valley and an abrupt layer 2A two-way time decrease off-axis. This two-way time decrease is caused by a layer $2 \mathrm{~A}$ velocity increase on the order of $1 \mathrm{~km} / \mathrm{s}$. The uniform two-way time in the median valley results from a constant thickness layer $2 \mathrm{~A}$, which could be caused by the existence of a porosity threshold linked to the lithologic lava/dike boundary. The regularity of the layer $2 \mathrm{~A} / 2 \mathrm{~B}$ interface within the median valley indicates that layer $2 \mathrm{~A}$ is built entirely inside the median valley. The off-axis velocity increase is consistent with hydrothermal alteration and the aging of the crust.

Citation: Seher, T., W. C. Crawford, S. C. Singh, and M. Cannat (2010), Seismic layer 2A variations in the Lucky Strike segment at the Mid-Atlantic Ridge from reflection measurements, J. Geophys. Res., 115, B07107, doi:10.1029/2009JB006783.

\section{Introduction}

[2] Upper oceanic crust at mid-ocean ridges consists mainly of basaltic pillow lava and sheeted dykes. The upper oceanic crust, named collectively layer 2 , is characterized seismically by a steep velocity gradient $\left(\sim 1-2 \mathrm{~s}^{-1}\right)$, while the lower crust, named layer 3 , has a low velocity gradient $\left(\sim 0.1 \mathrm{~s}^{-1}\right)$ [Spudich and Orcutt, 1980]. Seismic layer 2 is characterized by two, sometimes three sub-layers [Houtz and Ewing, 1976; Houtz, 1976]. For consistency we apply a subdivision in two sub-layers (2A and $2 \mathrm{~B})$ with velocities of $\sim 2-4 \mathrm{~km} / \mathrm{s}$ and $5-6 \mathrm{~km} / \mathrm{s}$, respectively, with a transition zone having a steep velocity gradient region at the lower part of layer 2A [Harding et al., 1989; Christeson et al., 1996; Collier and Singh, 1998; Hussenoeder et al., 2002a, $2002 \mathrm{~b}]$. The sudden velocity change between layers $2 \mathrm{~A}$ and 2B is caused by a change in porosities [Becker et al., 1982; Carlson and Herrick, 1990; Jacobson, 1992]. This change in porosities has been associated with different causes: (1) the pillow lava to sheeted dike transition, (2) an alteration front (below a certain depth pores have been sealed by alteration products), or (3) by a porosity threshold linked to increasing overburden pressures (below a certain depth

\footnotetext{
${ }^{1}$ Géosciences Marines, Institut de Physique du Globe de Paris, Paris, France.

${ }^{2}$ Now at Earth Resources Laboratory, Department of Earth, Atmospheric and Planetary Sciences, Massachusetts Institute of Technology, Cambridge, Massachusetts, USA.

Copyright 2010 by the American Geophysical Union. 0148-0227/10/2009JB006783
}

pores have been closed by the pressure of the overburden). A lithologic transition from pillow lava to sheeted dikes would create a porosity contrast due to the different emplacement processes and cooling history [Herron, 1982; Harding et al., 1993; Schouten et al., 1999; Becker et al., 2004]. This hypothesis is consistent with studies of exposed oceanic crust on land, for example the Oman ophiolite [Nicolas et al., 1988; Nicolas and Boudier, 1995; Boudier et al., 1997], and with seafloor outcrops, for example at the Hess Deep Rift part of the East Pacific Rise [Karson et al., 2002]. Hydrothermal circulation can alter the basaltic rocks through mineralization and pore clogging [Rohr et al., 1988; Jacobson, 1992]. Hydrothermal alteration decreases the velocity on a small scale, while the hydrothermal filling of voids decreases the porosity and hence increases the velocity on a larger scale [Carlson, 1998; Grevemeyer and Bartetzko, 2004]. As the study of Wilkens et al. [1991] indicates, the hydrothermal infilling of voids could give rise to a large velocity increase with only a small change in porosity (e.g., 5\%). The filling of voids causes a transition from high to low porosity extrusives, which is imaged seismically as a transition from a high velocity gradient to a low velocity gradient [Christeson et al., 1996]. Finally, both active extension (faults, fractures and fissures) and accretion may create porosity in the upper oceanic crust. Crack closure with depth due to increasing confining pressure decreases the porosity and creates a velocity increase [Bratt and Purdy, 1984; Christeson et al., 2007], which may explain the change in seismic velocities necessary for the layer $2 \mathrm{~A} / 2 \mathrm{~B}$ transition. The key assumption 
is that a specific pore size collapses under a certain pressure. If the rock matrix is dominated by pores of a specific volume or the seismic measurements are sensitive to porosity of a certain size, the pressure increase with depth may produce a porosity threshold.

[3] The layer $2 \mathrm{~A} / 2 \mathrm{~B}$ transition has been observed for zero-age crust in most spreading environments and its depth generally correlates with spreading rate: slow spreading oceanic ridges have a slightly thicker layer $2 \mathrm{~A}$ than fast spreading ridges [Carbotte and Scheirer, 2004]. On the fast spreading East Pacific Rise the average layer 2A thickness is $200 \mathrm{~m}$ [Harding et al., 1993], while, for the slow spreading Mid-Atlantic Ridge, layer 2A thicknesses between 350 and $800 \mathrm{~m}$ are common [Hussenoeder et al., 2002b; Minshull et al., 2003]. Layer $2 \mathrm{~A}$ thickness on intermediate spreading ridges appears to be more variable; it commonly lies between $200 \mathrm{~m}$ and $600 \mathrm{~m}$ for the Galápagos Ridge [Blacic et al., 2004] and Juan de Fuca Ridge [Cudrak and Clowes, 1993; McDonald et al., 1994; Canales et al., 2005; Van Ark et al., 2007; Nedimović et al., 2008] and between $400 \mathrm{~m}$ and $1 \mathrm{~km}$ for the Valu Fa Ridge [Day et al., 2001; Jacobs et al., 2007].

[4] Fast and intermediate spreading ridges, especially the East Pacific Rise and Juan de Fuca Ridge and to a lesser degree the Galápagos Ridge, have been studied in sufficiently great detail to allow generalizing observations of lateral and temporal variations in layer $2 \mathrm{~A}$. In segments with an axial high, the layer $2 \mathrm{~A}$ thickness of zero-age crust increases with the depth of the axial melt lens along the ridge axis [Buck et al., 1997]. Furthermore, layer 2A thickness on fast- and intermediate spreading ridges increases with distance from the ridge axis [Harding et al., 1993; Hooft et al., 2000; Canales et al., 2005]. This is believed to be because younger lava bury the initially shallow top of the sheeted dike complex as the layer passes through the neovolcanic zone [Harding et al., 1993]. Finally, at fast- and intermediate spreading ridges seismic velocities in seismic layer $2 \mathrm{~A}$ increase with distance from the ridge axis as a result of the aging of the oceanic crust, in particular the filling of open void spaces by hydrothermal alteration, and the related porosity decrease [Chapman and Hannay, 1994; Grevemeyer and Weigel, 1997; Sohn et al., 1997; Nedimović et al., 2008]. This agedependent porosity/permeability trend is in agreement with borehole observations [Becker and Fisher, 2000]. It has been suggested that layer $2 \mathrm{~A}$ velocities double over a period of $40 \mathrm{Ma}$, while the upper part of layer $2 \mathrm{~A}$ gradually thins [Houtz and Ewing, 1976; Jacobson, 1992]. However, recent studies indicate that upper crustal velocities rise rapidly in less than $10 \mathrm{Ma}$ [Carlson, 1998], while layer 2A thinning is marginal [Carlson and Jacobsen, 1994]. For the Juan de Fuca Ridge layer $2 \mathrm{~A}$ can be thinner on the sedimented ridge flanks than on the ridge axis, but no systematic layer $2 \mathrm{~A}$ thinning with age exists. The increase in layer $2 \mathrm{~A}$ velocities with crustal age depends critically on the local setting and the age of sediment burial of the crust appears to be a more important factor than crustal age [Nedimović et al., 2008].

[5] Most studies of layer 2A along the Mid-Atlantic Ridge have focused either on the OH-1 segment [Barclay et al., 1998; Hussenoeder et al., 2002b], which does not have a well developed median valley, or on the hot spot dominated Reykjanes Ridge [Navin et al., 1998; Peirce et al., 2007]. For the magma-rich Reykjanes Ridge, layer 2A thick- ness is observed to stay constant or decrease off-axis [Navin et al., 1998; Peirce et al., 2007]. At slow spreading ridges the neovolcanic zones is limited to the rift valley, where most extrusives are built. This process is disrupted during tectonically active periods [Hussenoeder et al., 2002b].

[6] Here, we analyze the lateral variability of seismic layer $2 \mathrm{~A}$ of the slow spreading Lucky Strike segment on the MidAtlantic Ridge. This ridge segment is particularly interesting, because a well-developed median valley and central volcano with a high temperature hydrothermal vents field create an ideal setting for the study of the interaction between tectonic, magmatic and hydrothermal processes in upper crustal formation. Here, we present a study of seismic layer 2A using seismic reflection data. We shot 24 multichannel seismic profiles covering the median valley and bounding walls of the Lucky Strike segment. We treated the near-offset part of layer $2 \mathrm{~A}$ turning waves like reflections from the bottom of layer $2 \mathrm{~A}$ permitting us to seismically image the layer $2 \mathrm{~A} / 2 \mathrm{~B}$ boundary. Our seismic reflection measurements cover the central $75 \%$ of the ridge segment and reach crust as old as $3 \mathrm{Ma}$, which allows us to image both spatial and temporal variations in the upper crust. The observations of seismic layer $2 \mathrm{~A}$ constrain processes defining the seismic structure of young oceanic crust.

\section{The Study Area}

[7] The Lucky Strike segment is located on the MidAtlantic Ridge south of the Azores hot spot and the Azores Triple Junction. The ridge segment is $\sim 70 \mathrm{~km}$ long and is delimited by non-transform offsets [Detrick et al., 1995; Parson et al., 2000]. The Lucky Strike segment has a $15 \mathrm{~km}$ to $20 \mathrm{~km}$ wide median valley, large $\sim 0.5 \mathrm{~km}$ high median valley bounding faults and a central volcano, which hosts high temperature hydrothermal vents [Langmuir et al., 1997]. An axial magma chamber is imaged seismically underneath the Lucky Strike volcano by an axial melt lens reflector [Singh et al., 2006; Combier, 2007] and underlying lower crustal low velocity zone [Seher et al., 2010a].

[8] As we explained above, magmatic, tectonic and hydrothermal processes all can potentially influence the properties of seismic layer 2A. There is significant evidence for recent magmatism at the Lucky Strike segment. The central volcano and the western volcanic ridge, a volcanic edifice extending north-west from the volcano show evidence for recent magmatic eruptions (see Figure 1a). The volcano holds a recent lava lake and the western volcanic ridge has fresh pillow lava [Fouquet et al., 1995; Humphris et al., 2002; Ondréas et al., 2009]. A teleseismic earthquake swarm registered on a regional hydrophone array is likely to be linked to a recent dike injection event [Dziak et al., 2004]. Tectonic processes also play an important role in the Lucky Strike segment. Photographic images reveal wide-spread axis-parallel faulting [Escartín et al., 2008]. There is evidence for a nascent fault system on top of the Lucky Strike volcano; a new seamount is constructed and is immediately rifted apart. Off-axis rifted volcanos prove the interplay between periods dominated by magmatism and tectonics (J. Escartín, personal communication, 2005). Further evidence for the complex tectonic processes at segment ends are the inside corner highs, elevated detachment surfaces linked to normal faulting [Karson and Dick, 1983; 


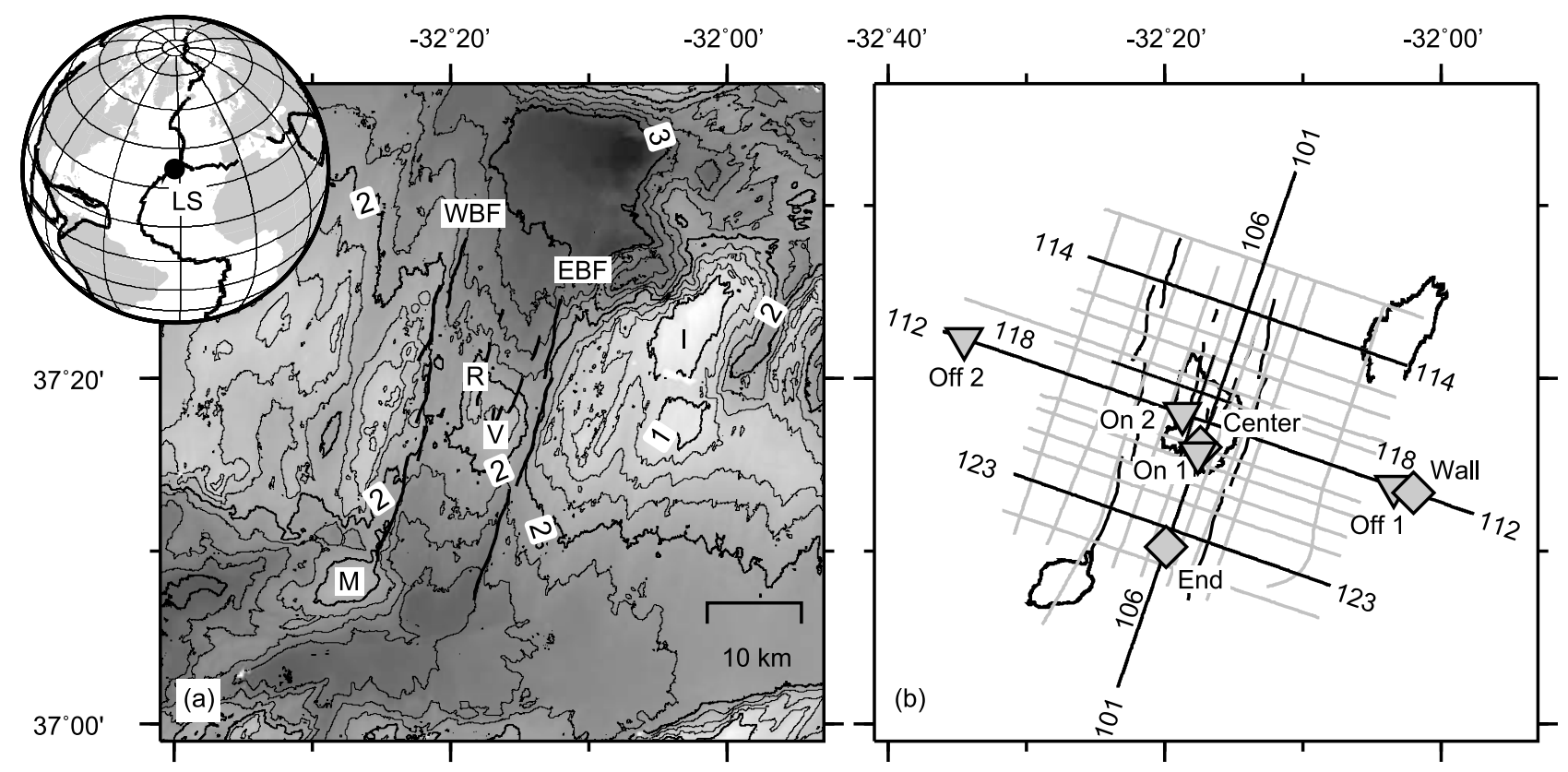

Figure 1. (a) Bathymetric map of the Lucky Strike segment with important features of the seafloor. V: Lucky Strike volcano. M: Menez Hom massif. I: Inside corner high. R: Volcanic ridge. WBF/EBF: Western/Eastern bounding fault. The solid black lines mark the eastern and western bounding fault and a nascent fault system. (b) Seismic reflection lines shot during the SISMOMAR cruise. The profiles marked in grey are used to constrain the lateral variability of seismic layer 2A and the profiles marked with black lines are discussed in more detail. The grey triangles and diamonds mark the positions of reference shot and CMP gathers shown in Figures 2 and 5, respectively. The bathymetric contours marking the Menez Hom massif, Lucky Strike volcano and inside corner high as well as the bounding faults are shown for orientation. The inset globe shows the Lucky Strike segment (LS) on the Mid-Atlantic Ridge. The major plate boundaries are marked as solid black lines [Müller et al., 1997].

Severinghaus and MacDonald, 1988; Ranero and Reston, 1999]. Hydrothermal circulation is observed both on the Lucky Strike volcano and the Menez Hom massif (see Figure 1a). While the Lucky Strike hydrothermal field is hosted in a basaltic environment, the Menez Hom hydrothermal system, close to the southern segment end, is hosted in an ultramafic setting [Marques et al., 2007].

\section{SISMOMAR Segment-Scale Reflection Experiment}

[9] We analyze seismic reflection data from a twodimensional grid of 24 shot lines spaced $\sim 2.5 \mathrm{~km}$ apart collected along and across the Lucky Strike segment during the 2005 SISMOMAR cruise (see Figure 1b). These shot lines provide reflection data out to the segment ends and up to $30 \mathrm{~km}$ off-axis. The observations of layer $2 \mathrm{~A}$ cover a rectangular area of $54 \mathrm{~km}$ along the ridge axis and $60 \mathrm{~km}$ across. The air guns were tuned to generate a single bubble pulse [Avedik et al., 1993, 1996] and had an array volume of 8410 cubic inches. The shot spacing was $150 \mathrm{~m}$, which corresponds to 1 shot every minute. The large volume seismic source and large delay between two successive shots were chosen to optimize the data for a coincident seismic refraction survey [Seher et al., 2010a]. The data were recorded on a 360 channel, $4.5 \mathrm{~km}$ long digital streamer. The receiver group spacing of the seismic streamer was $12.5 \mathrm{~m}$ and the near hydrophone offset was $185 \mathrm{~m}$. The data were sampled every $4 \mathrm{~ms}$. The shot positions were determined from a differential GPS system and were corrected for the offset between the ship and the air gun array. For the seismic reflection survey the large shot point spacing meant a low fold of 15 in each common midpoint (CMP) gather.

\section{Data Processing}

[10] Our seismic shot gathers show prominent sub-seafloor arrivals at medium and large offsets $(>2.5 \mathrm{~km}$ ) (Figure 2). Those arrivals correspond to seismic waves turning in the lower part of layer $2 \mathrm{~A}$ and the upper part of layer 2B [Vera et al., 1990; Harding et al., 1993]. In order to get a first impression of the velocity variation in the Lucky Strike segment, we analyze shot gathers recorded close to the Lucky Strike volcano on the ridge axis and shot gathers recorded on the median valley wall.

[11] Here, we apply two-way time (TWT) forward modeling to identify the different seismic events in a single shot gather and estimate a subsurface velocity-depth profile. We manually change a simple velocity-depth profile and calculate synthetic TWT using the tomography code by Hobro et al. [2003] to reproduce the seismic arrivals observed in a shot gather. The subsurface is represented using a one-dimensional velocity-depth profile draped underneath the seafloor taking into account the three-dimensional variation of the seafloor.

[12] The first prominent event is a retrograde event from rays turning in the transition zone $(2 \mathrm{~A})$ and the second 


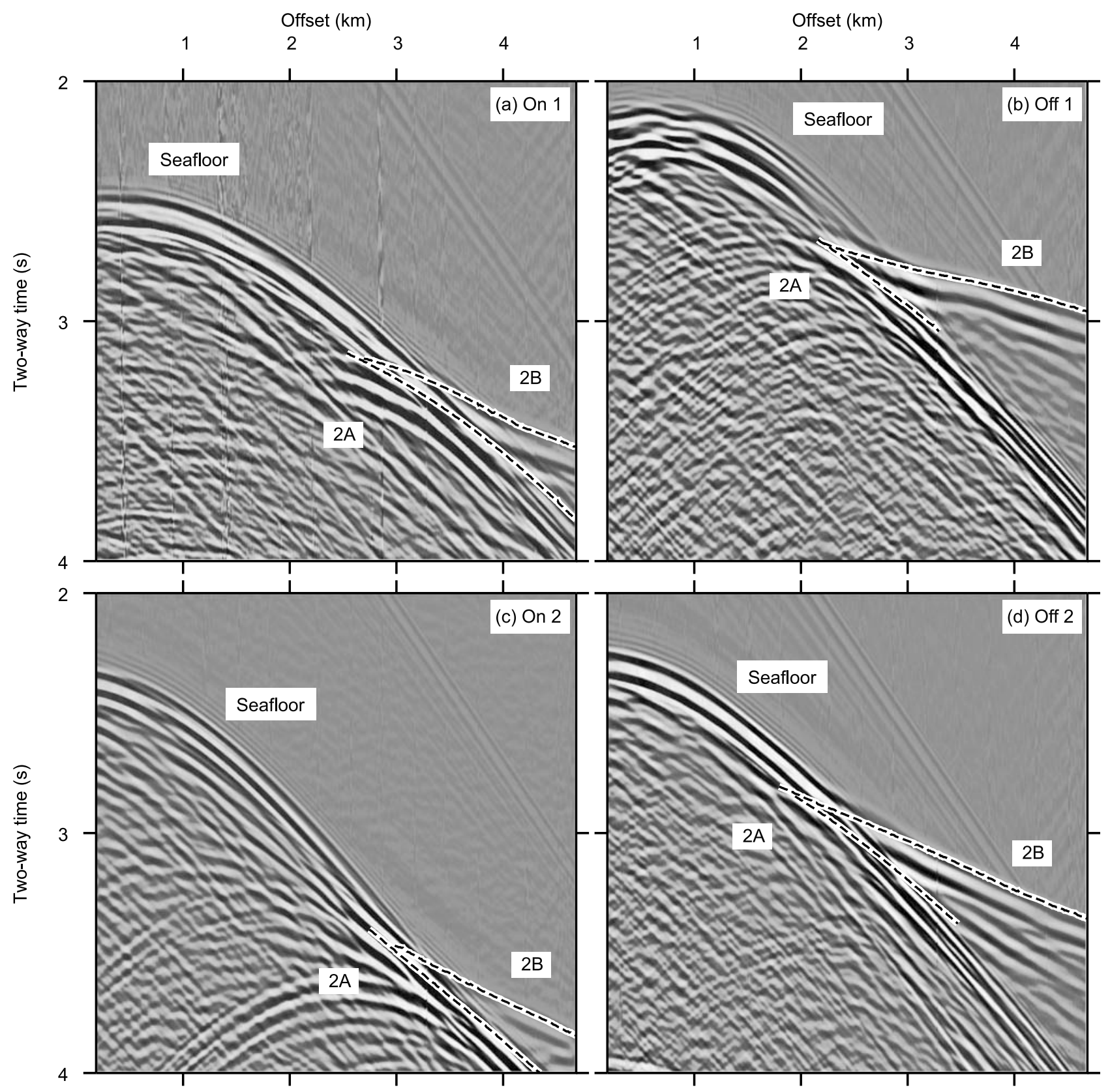

Figure 2. Shot gathers recorded during the SISMOMAR experiment. (a and c) Shot gathers recorded on the ridge axis near the central Lucky Strike volcano. ( $b$ and d) Shot gathers recorded off-axis (see Figure 1 for location of the shot gathers). The modeled TWT for the retrograde $2 \mathrm{~A}$ arrival (2A) and the prograde $2 \mathrm{~B}$ arrival are shown superimposed on the shot gathers. The velocity models used for calculating the TWT are shown in Figure 3.

arrival is prograde, from rays turning in layer $2 \mathrm{~B}$ (Figure 2). The velocity models and raypaths are shown in Figures 3 and 4. Prograde arrivals from rays turning in the upper part of layer $2 \mathrm{~A}$ have not been identified. Without a detectable prograde $2 \mathrm{~A}$ event, the data provide no constraints on velocity structure of shallowmost layer 2A. Synthetic modeling the prograde arrivals indicates that this event interferes with the seafloor reflection making it difficult to recognize in the shot gathers. We arbitrarily chose the velocity in the upper part of layer $2 \mathrm{~A}$ to closely match the velocity observed in the OH-1 segment [Hussenoeder et al., 2002b].

[13] The velocity-depth profiles used to fit the seismic data are shown in Figure 3 after correction for the seafloor depth. The velocity structure shows a low-velocity and lowgradient layer $2 \mathrm{~A}$, a transition zone with a steep velocity gradient and a higher-velocity but low-gradient layer $2 \mathrm{~B}$. The transition zone is considered to be part of layer $2 \mathrm{~A}$ [Hussenoeder et al., 2002b]. Due to the absence of clear prograde layer 2A arrivals, near-surface velocities are poorly constrained in our velocity models. The better con- 


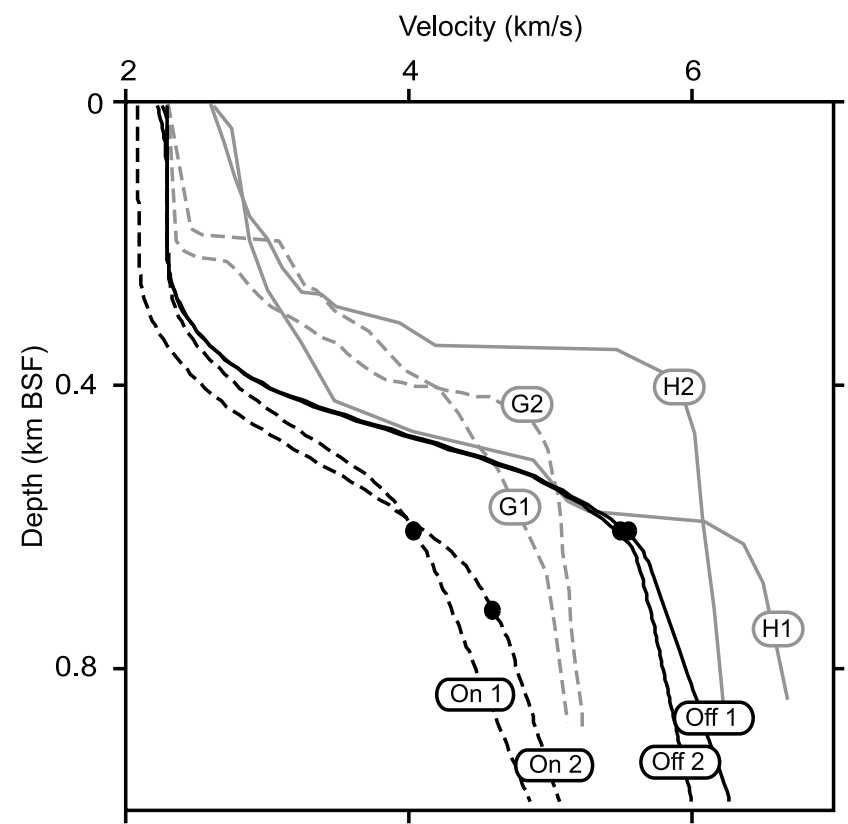

Figure 3. Comparison of on-axis and off-axis velocity structure (see Figure 1 for location of the shot gathers). The black points mark the approximate location of the layer $2 \mathrm{~A} / 2 \mathrm{~B}$ boundary. The velocities shown here were used in modeling the shot gathers shown in Figure 2. For comparison we show velocity models for the $\mathrm{OH}-1$ segment in grey [Hussenoeder et al., 2002b]. G1 and G2 were located in the segment center and $\mathrm{H} 1$ and $\mathrm{H} 2$ off-axis. Depth given in $\mathrm{km}$ below seafloor (BSF).

strained velocities at the bottom of layer $2 \mathrm{~A}$ are $\sim 1 \mathrm{~km} / \mathrm{s}$ faster off-axis than on-axis. The average velocity to the layer $2 \mathrm{~A} / 2 \mathrm{~B}$ boundary is $\sim 2.6 \mathrm{~km} / \mathrm{s}$ at the segment center and $\sim 2.8 \mathrm{~km} / \mathrm{s}$ off-axis. The bottom of seismic layer $2 \mathrm{~A}$ is located $\sim 0.55-0.65 \mathrm{~km}$ below seafloor on all four velocitydepth profiles.

[14] For comparison with our velocity models we show velocity models for the $\mathrm{OH}-1$ segment [Hussenoeder et al., 2002b] (Figure 3). Models G1 and G2 were located in the rift valley and models $\mathrm{H} 1$ and $\mathrm{H} 2$ on the eastern terrace. This comparison shows that the models by Hussenoeder et al. [2002b] are slightly thinner and faster for both on- and off-axis locations than the Lucky Strike models. This difference is to be expected due to the velocity-depth trade-off in our analysis. More importantly, off-axis velocities are significantly faster $(\sim 1 \mathrm{~km} / \mathrm{s})$ than on-axis velocities in both the Lucky Strike and $\mathrm{OH}-1$ segments.

[15] To verify whether the off-axis velocity increase of $\sim 1 \mathrm{~km} / \mathrm{s}$ is significant, we compare the TWT predicted using the off-axis and on-axis velocity models (Figures $4 \mathrm{a}$ and 4b). Overall, we observe that the on-axis velocity-model does not fit the off-axis data and vice versa. In particular, the on-axis velocity model fails to reproduce the whole offset range of observed off-axis layer 2B arrivals. This comparison demonstrates that most constraints in our velocity models are based on the TWT of the caustic and the slope of layer $2 \mathrm{~B}$ arrivals. The constraints we were able to derive from retrograde layer $2 \mathrm{~A}$ arrivals are minor due to interference with the seafloor reflection.
[16] To further analyze the seismic data, we apply stack based seismic imaging using a standard processing sequence: geometry definition, trace interpolation, normal moveout correction, dip moveout correction, stack and time migration [Yilmaz, 1987]. Since the layer 2A/2B transition does not create observable reflections, we use turning wave energy to image this boundary. For small offsets the TWT of the retrograde transition zone turning wave $(2 \mathrm{~A})$ and of the prograde layer $2 \mathrm{~B}$ turning wave $(2 \mathrm{~B})$ are asymptotic to a hypothetical reflection from the bottom of the transition zone. Since the TWT in the caustic is asymptotic to the TWT of an reflector, we stack turning waves to obtain a seismic reflector image [Harding et al., 1993].

[17] The first step in processing seismic reflection data is to set up the data processing geometry. Since the profile spacing is too large for a full three-dimensional treatment, we chose to treat the data in two dimensions and assume the seismic streamer follows the course of the ship (i.e. there is no streamer feathering). Two static time corrections were applied to the seismic traces to account for the streamer and air gun depths as well as the time lag between the trigger and the air gun release. For this experiment the time lag varied between $22.1 \mathrm{~ms}$ and $44.1 \mathrm{~ms}$.

[18] The next step is to determine the usable seismic bandwidth and band-pass filter the data to enhance the signal-to-noise ratio. Examining the spectral amplitude of the measured seismic data shows that most of the energy is contained between 5 and $35 \mathrm{~Hz}$. Seismic deconvolution was not applied in this study because of problems related to the treatment of an unknown mixed-phase source wavelet. Applying a Wiener spiking deconvolution did not improve the seismic image significantly.

[19] The shot spacing was $150 \mathrm{~m}$ and the receiver spacing $12.5 \mathrm{~m}$, which yields a CMP trace spacing of $300 \mathrm{~m}$ and a fold of 15. A large trace spacing in a CMP gather can cause spatial aliasing, which we avoid by trace interpolation. In order to decrease the trace spacing, the seismic data were sorted into receiver domain and interpolated to $37.5 \mathrm{~m}$ trace spacing. Reordering the data in CMPs increases the trace spacing to $75 \mathrm{~m}$ and the fold to 60 . The interpolation applied here is based on estimating the semblance via a local slant stack [Schultz and Claerbout, 1978] for all the traces within a spatial window [Spitz, 1991; Porsani, 1999].

[20] Next, we applied a dip moveout (DMO) and a normal moveout (NMO) correction [Yilmaz, 1987], before stacking the data. The NMO and DMO correction correct the layer $2 \mathrm{~A} / 2 \mathrm{~B}$ event to its normal incidence TWT. Furthermore, the DMO correction reduces scattered waves from shallow diffractors and causes some CMP smearing [Klinkby and Pedersen, 1998], which enhances the continuity of the layer $2 \mathrm{~A} / 2 \mathrm{~B}$ event. The $\mathrm{NMO}$ correction is combined with a stretch mute to avoid frequency distortion. To apply the DMO correction, the seismic traces are resampled to equal offsets, then transformed into the frequency-wave number domain, where the DMO operator [Notfors and Godfrey, 1987; Liner, 1990; Black et al., 1993] is applied. The data are then transformed back into time-offset domain.

[21] To demonstrate the presence of layer $2 \mathrm{~A} / 2 \mathrm{~B}$ energy in the data, we show three representative super-CMP gathers located close to the segment end, at the segment center and at the eastern median valley wall (Figure 5). After band-pass 

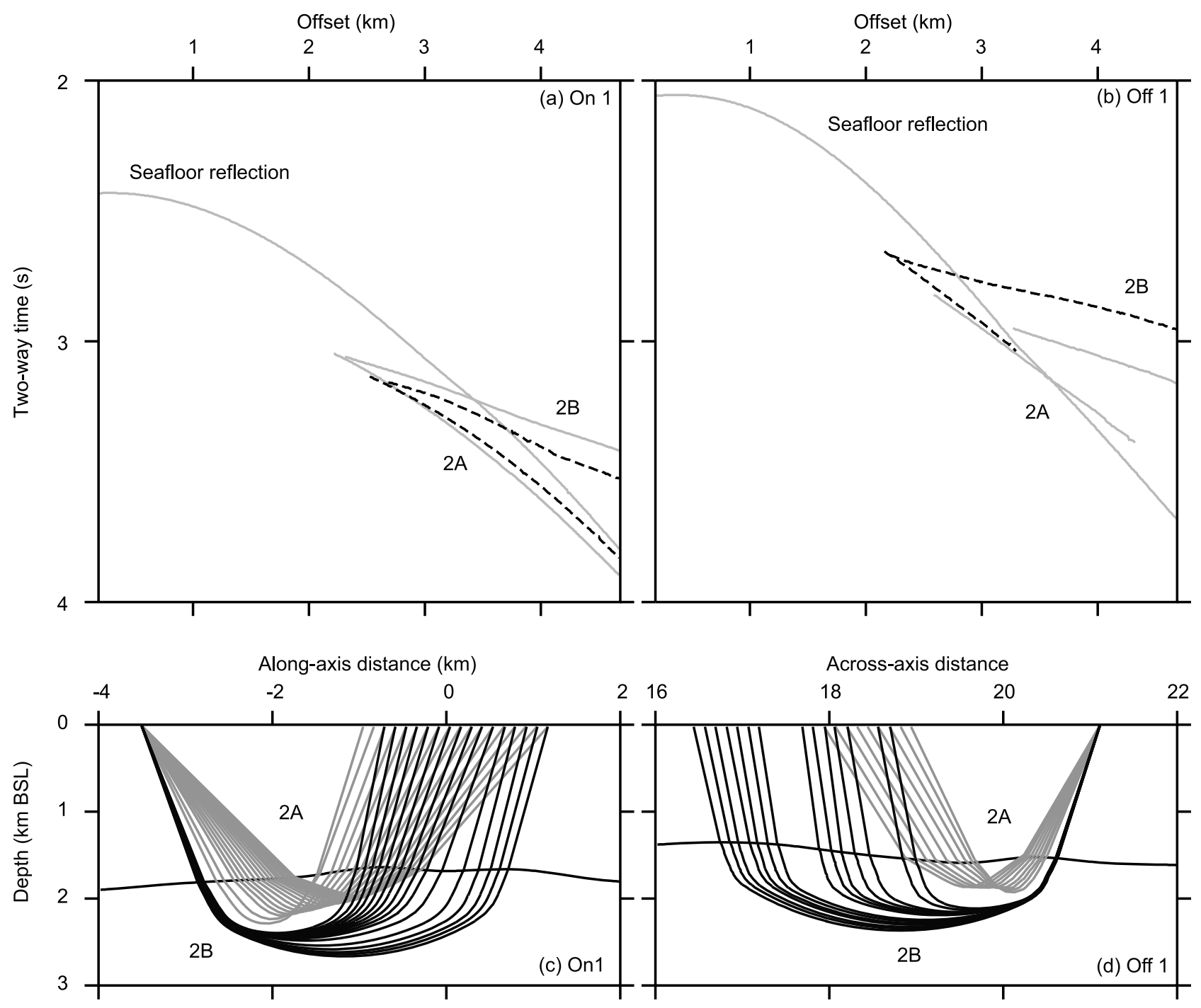

Figure 4. Synthetic TWT and associated raypaths for one location on the ridge axis and one location on the ridge flank. ( $a$ and $b$ ) The synthetic TWT for the velocity models, which best fit the TWT observations in Figures $2 \mathrm{a}$ and $2 \mathrm{~b}$, are marked with a dashed black line and (c and d) the associated raypaths. The number of rays shown here has been reduced by a factor 10. To illustrate the difference between the ridge axis and ridge flank velocity models, we show synthetic TWT that were estimated assuming the off-axis velocity model for the ridge axis and vice versa (grey line in Figures $4 a$ and $4 b$ ).

filtering, trace interpolation and normal moveout correction, we combined $11 \mathrm{CMP}$ gathers into one super-CMP gather. All three super-CMP gathers show the caustic marking the layer $2 \mathrm{~A} / 2 \mathrm{~B}$ transition, which we stack to image the variability of seismic layer $2 \mathrm{~A}$. Two choices influence the stacked image: the choice of the NMO velocity and the choice of the stacked offset range.

[22] The image quality depends on the selection of appropriate NMO velocities. To choose the NMO velocities, constant velocity stacks were calculated for a variety of velocities (Figure 6). The seafloor and the layer $2 \mathrm{~A} / 2 \mathrm{~B}$ transition are recognizable at NMO velocities of $1.8,1.9$ and $2.0 \mathrm{~km} / \mathrm{s}$. In the median valley the layer $2 \mathrm{~A} / 2 \mathrm{~B}$ event is best imaged using a NMO velocity of $1.9 \mathrm{~km} / \mathrm{s}$. Choosing a lower or higher velocity deteriorates the image quality. Offaxis a higher NMO velocity of $2.0 \mathrm{~km} / \mathrm{s}$ gives a slightly better layer $2 \mathrm{~A} / 2 \mathrm{~B}$ image. If we compare the images obtained using a constant velocity to those obtained using a manually selected NMO velocity that carefully aligns the layer $2 \mathrm{~A} / 2 \mathrm{~B}$ event, the image quality is comparable whether we choose a constant velocity model or manually pick the stacking velocity.

[23] The second choice influencing the image quality is the choice of the stacked offset range. While the seafloor contributes mostly at small offsets, the layer $2 \mathrm{~A} / 2 \mathrm{~B}$ transition can be observed only at offsets larger than $1.5 \mathrm{~km}$. Therefore, we carefully picked a mute to remove layer $2 \mathrm{~B}$ turning wave energy and only stack energy close to the caustic. Compared to a constant velocity stacks without mute the image of the layer $2 \mathrm{~A} / 2 \mathrm{~B}$ event does not improve after application of a top-mute (Figure 6). This is caused by the application of a NMO correction prior to stack. Layer 2B energy at far offsets is removed by the stack. 

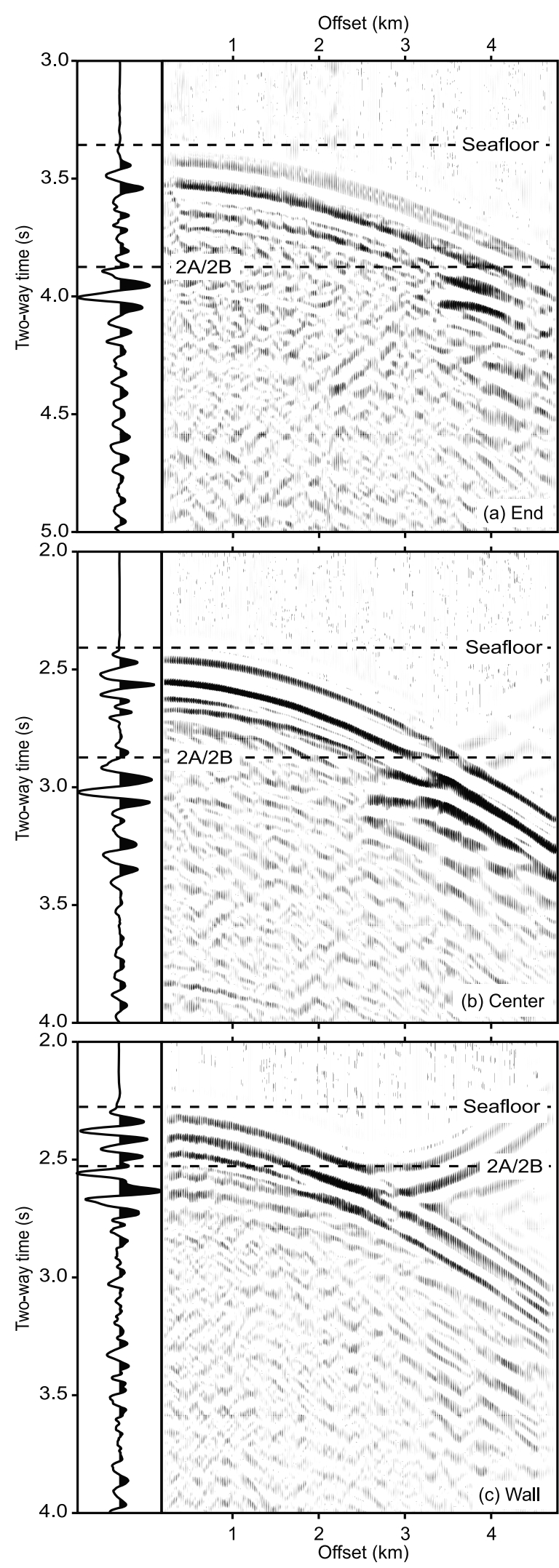

[24] We conclude that we can stack the seismic data using a constant velocity without muting layer $2 \mathrm{~B}$ energy. After analyzing constant velocity stacks for all seismic profiles, we chose a one-dimensional (1D) sub-seafloor velocity profile to stack all seismic profiles. We used an NMO velocity of $1.9 \mathrm{~km} / \mathrm{s}$ from the sea surface down to $0.75 \mathrm{~s}$ below the seafloor, to obtain an optimum image of layer $2 \mathrm{~A}$, and $3.1 \mathrm{~km} / \mathrm{s}$ from $1 \mathrm{~s}$ down, to image later events [compare Singh et al., 2006]. Those two constant velocity regions are connected by a linear velocity gradient. The seafloor reflection can be observed at small offsets, which are only mildly affected by the choice of the stacking velocity. Therefore, the seafloor event stacks well at velocities slightly larger than the water velocity. Our approach of using the same model everywhere assures line-to-line comparability: no variations are introduced into the image by variations of the velocity model.

[25] To estimate the uncertainty introduced by the choice of a NMO velocity, we compare the TWT for refracted arrivals at different NMO velocities with those of theoretical reflected arrivals. Here, we estimated the TWT for reflections by assuming a sharp interface at the top and the bottom of the transition zone. Figures $7 \mathrm{a}$ and $7 \mathrm{~b}$ show a comparison of turning wave TWT and TWT for a reflector after applying a NMO correction of $1.8 \mathrm{~km} / \mathrm{s}, 1.9 \mathrm{~km} / \mathrm{s}$ and $2.0 \mathrm{~km} / \mathrm{s}$, respectively. The velocity models used in modeling are shown in Figure 3. When stacking the seismic data, the near-offset part of the seismic events behaves like a reflection delineating the bottom of the transition zone. The far-offset part of the seismic events shown here cancels in the summation. In conclusion, if the NMO velocity is carefully chosen, turning wave arrivals originating inside the transition zone can be used to map the layer $2 \mathrm{~A} / 2 \mathrm{~B}$ transition [Harding et al., 1993]. With an appropriate normal moveout, velocity arrivals from both the upper part of layer $2 \mathrm{~A}$ and $2 \mathrm{~B}$ are unlikely to contribute significantly to the image when stacking the data. Choosing a different NMO velocity shifts the TWT of the caustic, the time at which the turning wave energy contributes to the seismic image. This choice contributes $\sim 60 \mathrm{~ms}$ to the TWT uncertainty in our seismic image.

[26] The last step in our seismic processing sequence is post-stack frequency-wave number constant velocity time migration [Stolt, 1978; Stolt and Benson, 1986] with a migration velocity of $1.5 \mathrm{~km} / \mathrm{s}$. This significantly reduces the effect of scattering from the rough seafloor. Depth migration cannot be applied because the velocity structure inside layer $2 \mathrm{~A}$ is poorly known. Since we use turning waves and not true reflections, the stacking velocity does not constrain the upper crustal velocity. Velocity models

Figure 5. Normal moveout corrected super-CMP gathers and resulting stacked trace. The pre-stack processing involved band-pass filtering $(5-35 \mathrm{~Hz})$, trace interpolation, normal moveout correction with a velocity of $1.9 \mathrm{~km} / \mathrm{s}$ and construction of super gathers from 11 CMP gathers. The approximate position of the seafloor reflection and the layer $2 \mathrm{~A} / 2 \mathrm{~B}$ transition is marked on all gathers. The CMP gathers are located at (a) the southern segment end, (b) the segment center and (c) the eastern median valley wall (CMP locations shown in Figure 1). 


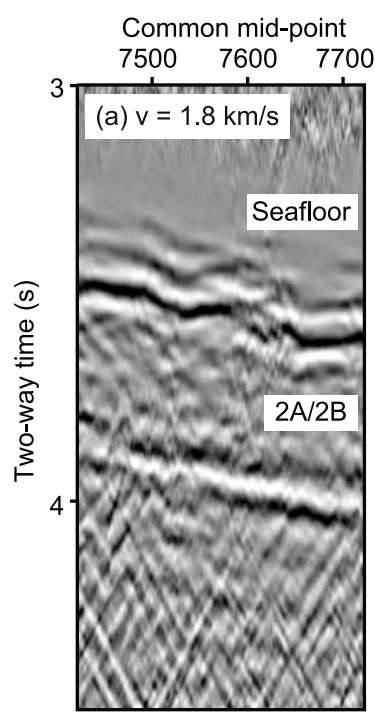

Common mid-point $56005700 \quad 5800$

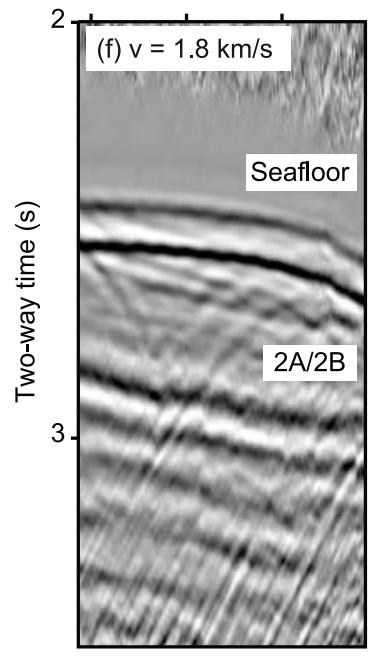

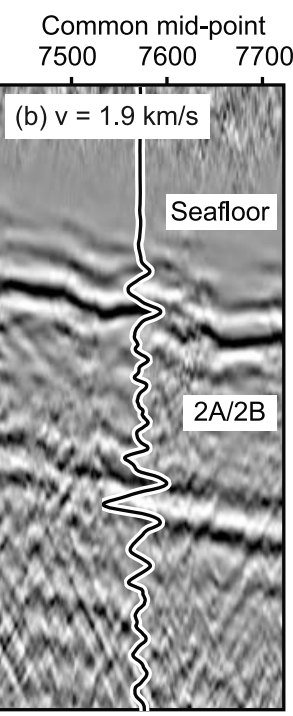

Common mid-point $5600 \quad 5700 \quad 5800$

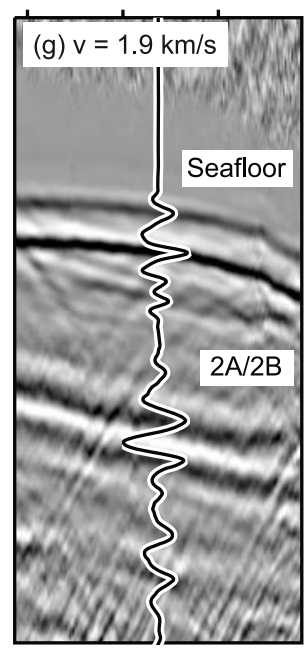

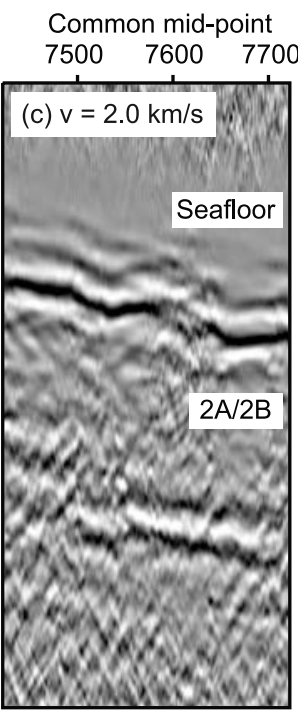

Common mid-point $5600 \quad 5700 \quad 5800$

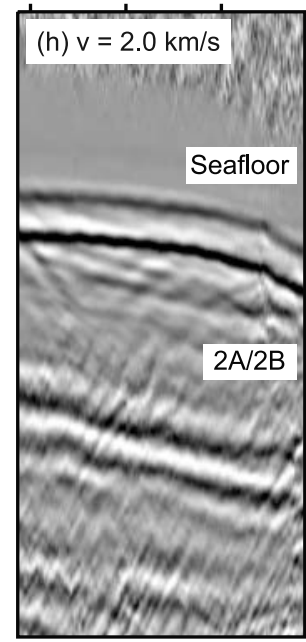

Common mid-point \begin{tabular}{lll}
$7500 \quad 7600 \quad 7700$ \\
\hline
\end{tabular}

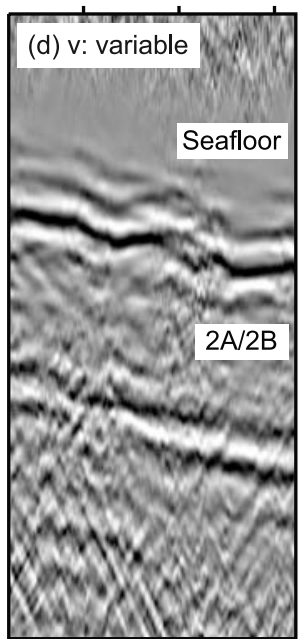

Common mid-point $5600 \quad 5700 \quad 5800$

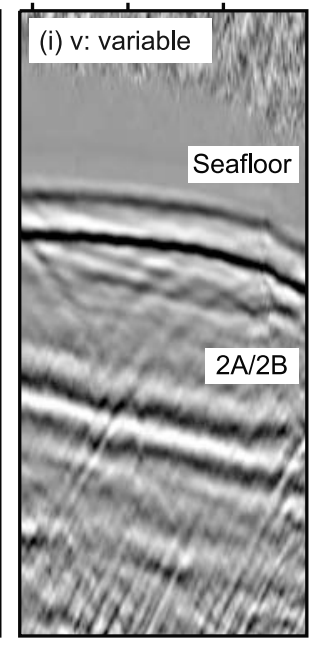

Common mid-point

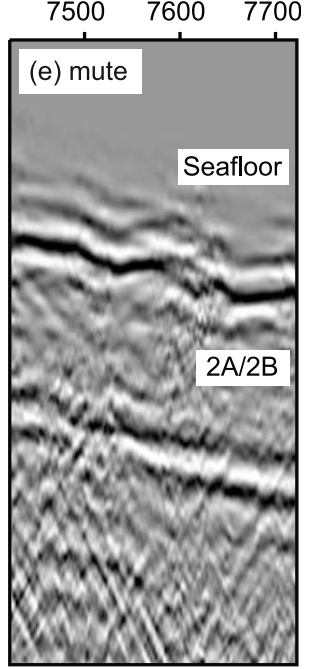

Common mid-point $5600 \quad 5700 \quad 5800$

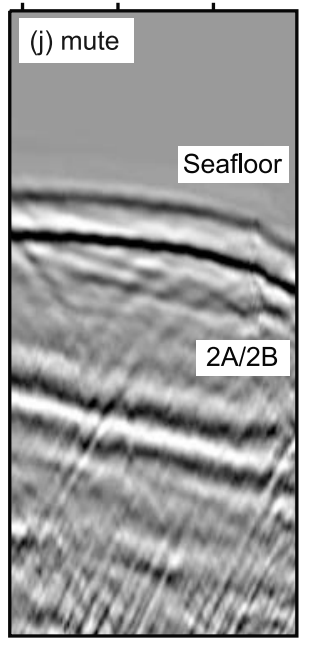

Common mid-point $\times 10^{5}$ Common mid-point $\times 10^{5}$ Common mid-point $\times 10^{5}$ $\begin{array}{llllll}1.629 & 1.630 & 1.631 & 1.629 & 1.630 & 1.631\end{array}$
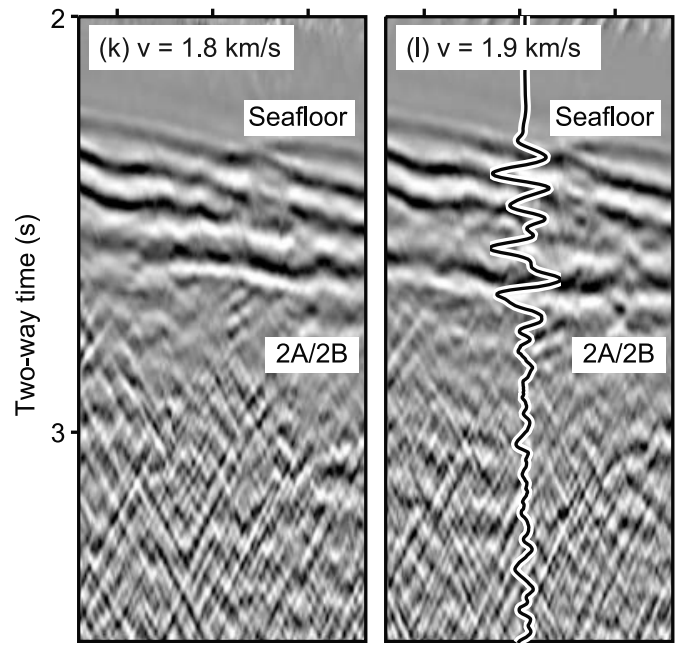

Common mid-point $\times 10^{5}$ Common mid-point $\times 10^{5}$

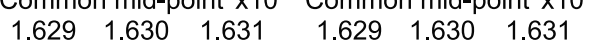

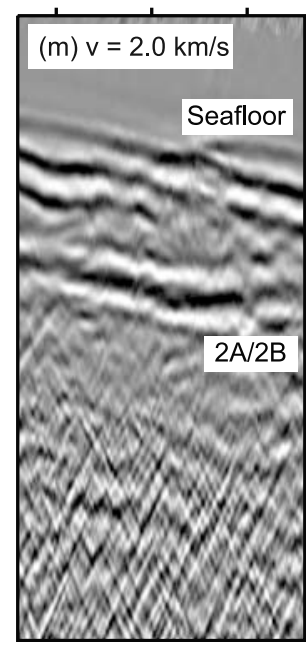

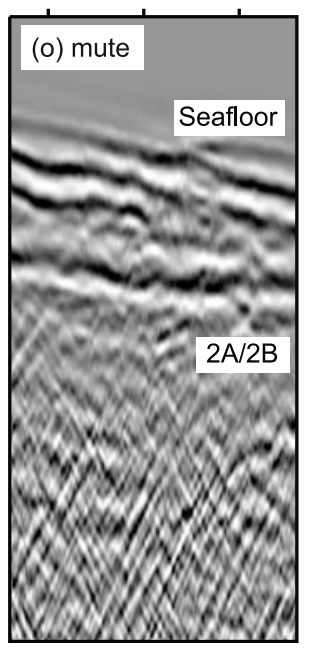

Figure 6 

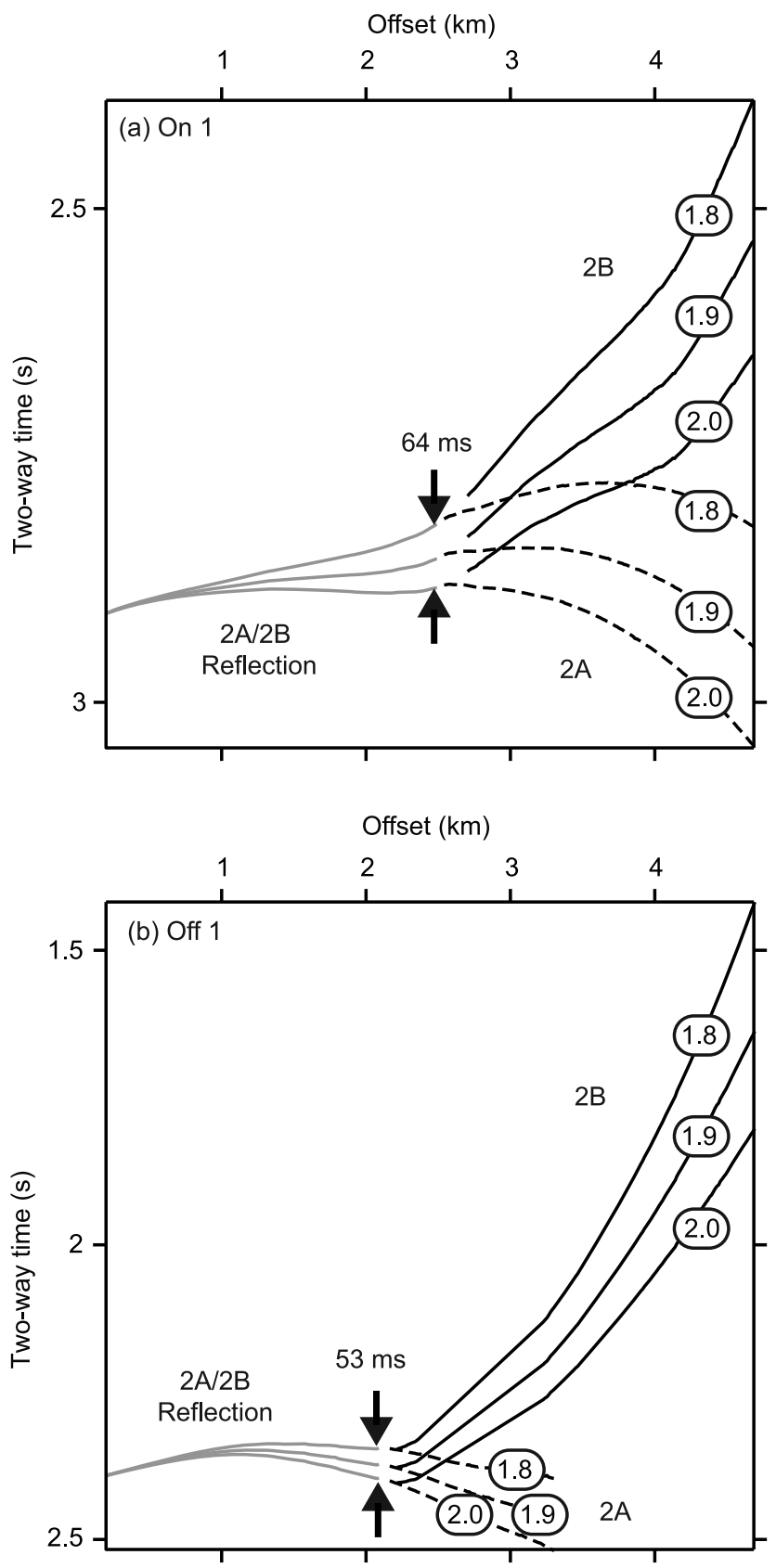

Figure 7. A comparison of TWT for a reflection from the bottom of seismic layer $2 \mathrm{~A}$, the retrograde layer $2 \mathrm{~A}$ event (2A) and the prograde layer $2 \mathrm{~B}$ event (2B) shows that in the caustic the turning rays are asymptotic to a reflection. The TWT were estimated using the (a) on-axis and (b) offaxis velocity models shown in Figure 3 . The numbers on each TWT curve denote the normal moveout velocity and the arrows denote the TWT variability caused by the choice of one stacking velocity. from the coincident seismic refraction experiment have a large uncertainty in layer 2A [Seher, 2008; Seher et al., 2010a, 2010b].

[27] Having processed the seismic data into a seismic image, the next step is to interpret this image. The horizons are picked manually by digitizing the seafloor and the layer $2 \mathrm{~A}$ event. Adjacent picks were automatically interpolated by following either a minimum/maximum amplitude or a zero crossing. Because a bubble tuned source was used to enhance the low frequency content of the signal, picking the first break proved difficult. The first break is weak compared to other parts of the seismic wavelet. Picking on maximum amplitude and then shifting the picks to first break is more practical.

[28] The TWT inside layer $2 \mathrm{~A}\left(\Delta \mathrm{TWT}_{S F-2 A}\right)$ was calculated by subtracting the TWT to the seafloor $\left(\mathrm{TWT}_{\mathrm{SF}}\right)$ and to the layer $2 \mathrm{~A}$ event $\left(\mathrm{TWT}_{2 \mathrm{~A}}\right)$. To carry out the differentiation, we need to address two problems: the non-continuous sampling of the interfaces and the short wavelength noise created by the numerical differentiation. We addressed the non-continuous sampling by interpolating the picks to a regular spacing, while keeping track of unsampled regions. The problem of short wavelength noise was resolved by low-pass filtering the input data sets prior to the differentiation using a Gaussian filter with a total full-width at half maximum of $709 \mathrm{~m}$ (113 CMP). Low-pass filtering removes short wavelength variations caused by changes in bathymetry.

\section{Results}

[29] Generally, the seafloor and layer 2A appear more continuous on profiles running along the ridge axis. This is due to the fact that the strike of the major faults is ridge parallel and the seafloor varies less in this direction, which improves the quality of the seismic images. The dominant strike of the major faults causes the seafloor and layer $2 \mathrm{~A}$ to vary more abruptly on profiles across the ridge axis than on profiles along the ridge axis (Figures 8, 9, 10, and 11). While large changes in TWT are observed across the ridge axis, the TWT varies rather smoothly along the ridge axis.

[30] On along-axis profile 101 (Figure 8), which runs directly across the Lucky Strike volcano, $\mathrm{TWT}_{2 \mathrm{~A}}$ follows $\mathrm{TWT}_{\mathrm{SF}}$ and $\triangle \mathrm{TWT}_{S F-2 A}$ is uniform over most of the ridge segment. A slight $\triangle \mathrm{TWT}_{S F-2 A}$ increase is observed at the southern end of the profile for along-axis distances between $20 \mathrm{~km}$ and $30 \mathrm{~km}$ (Figure 8). Comparing the variations of layer 2A with the bathymetry along the central part of the median valley (Figure 8c) shows the abundance of volcanic features and faults. While the central volcano is characterized by flat lava, numerous volcanic ridges can be observed farther south.

[31] Across the ridge axis, layer $2 \mathrm{~A}$ is imaged almost continuously. Figures 9 and 10 show the variability of seismic layer $2 \mathrm{~A}$ in this direction $\sim 13 \mathrm{~km}$ north of the

Figure 6. Influence of the choice of the stacking velocity on the image quality at (a-e) the southern segment end, (f-j) the segment center and $(\mathrm{k}-\mathrm{o})$ the eastern valley wall. The first three panels in each row show 400 traces stacked using a constant moveout velocity of $1.8,1.9$ and $2.0 \mathrm{~km} / \mathrm{s}$ respectively and a $65 \%$ stretch mute. The fourth column shows 400 traces stacked using a variable moveout velocity that was picked manually to enhance the image of the layer $2 \mathrm{~A} / 2 \mathrm{~B}$ transition. Special care was taken to choose faster stacking velocities off-axis than in the median valley. The fifth column shows 400 traces stacked using a constant moveout velocity of $1.9 \mathrm{~km} / \mathrm{s}$ after application of top mute to remove energy turning in layer $2 \mathrm{~B}$. The wiggle traces $(b, g, l)$ correspond to the stacked traces shown in Figure 5. 


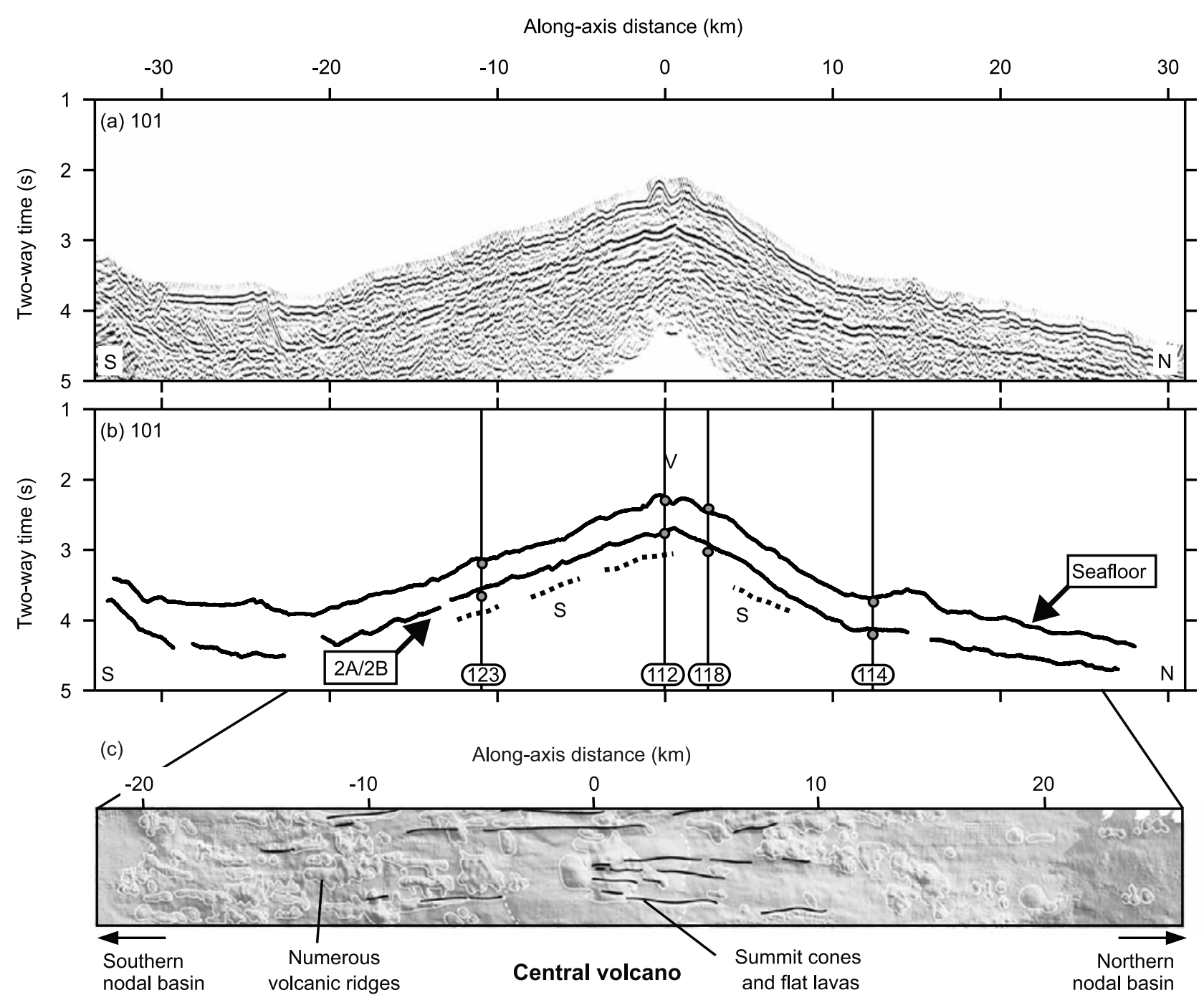

Figure 8. Along-axis variation of the seismic layer $2 \mathrm{~A} / 2 \mathrm{~B}$ boundary. The origin of the coordinate system corresponds to the location of the Lucky Strike volcano (V). The sub-layer 2A events (S) are possibly linked to sideswipe. (a) Time migrated image. (b) Interpretation of the image showing the seafloor reflection, the layer $2 \mathrm{~A} / 2 \mathrm{~B}$ boundary and several sub-layer $2 \mathrm{~A}$ events. The black lines mark the location of crossing profiles (see Figure 1 for the profile location) and the grey dots mark the corresponding seafloor and layer 2A/2B picks. (c) Bathymetry along the median valley to highlight volcanic features and faults (black lines). The profile runs from south to north.

segment center, at the segment center and $12 \mathrm{~km}$ south of the segment center. $\Delta \mathrm{TWT}_{S F-2 A}$ decreases abruptly in the vicinity of the median valley bounding faults and decreases more gradually underneath the flanks of the median valley. Most importantly, $\Delta \mathrm{TWT}_{S F-2 A}$ is larger on-axis than off-axis.

[32] The variation of layer 2A underneath the Lucky Strike seamount is of particular interest, because it contains information about the construction of the volcano and the porosity and permeability structure allowing the existence of the Lucky Strike hydrothermal vent field. Across-axis, $\triangle \mathrm{TWT}_{S F-2 A}$ is largest underneath the Lucky Strike volcano (Figures 9 and 10). The weak sub-layer 2A reflectors underneath Lucky Strike volcano (Figures 8 and 11) are likely caused by sideswipe, since those events cannot be observed on our across-axis profiles.
[33] The interpretation of faults shown here is not based on subsurface fault reflections, because the large shot point spacing $(150 \mathrm{~m})$ and profile spacing $(\sim 2 \mathrm{~km})$ in this study make it difficult to image the faults directly. For comparison during the high-resolution study of the Lucky Strike volcano, a smaller shot point spacing $(37.5 \mathrm{~m})$ and profile spacing $(0.1 \mathrm{~km})$ allowed the direct imaging of fault reflections [Combier, 2007]. However, displacements of the seafloor and layer $2 \mathrm{~A}$ events can be used to identify fault positions. All three across-axis seismic profiles (Figures 9, 10, and 11) show large vertical displacements of the seafloor and layer $2 \mathrm{~A}$ events caused by the eastern and western median valley bounding faults. Furthermore, multiple deep incisions into the seafloor are observable parallel to the ridge axis outside the median valley.

[34] To image the lateral variation of the layer $2 \mathrm{~A} / 2 \mathrm{~B}$ boundary, we assigned each $\mathrm{TWT}_{\mathrm{SF}}, \mathrm{TWT}_{2 \mathrm{~A}}$ and $\Delta \mathrm{TWT}_{S F-2 A}$ 

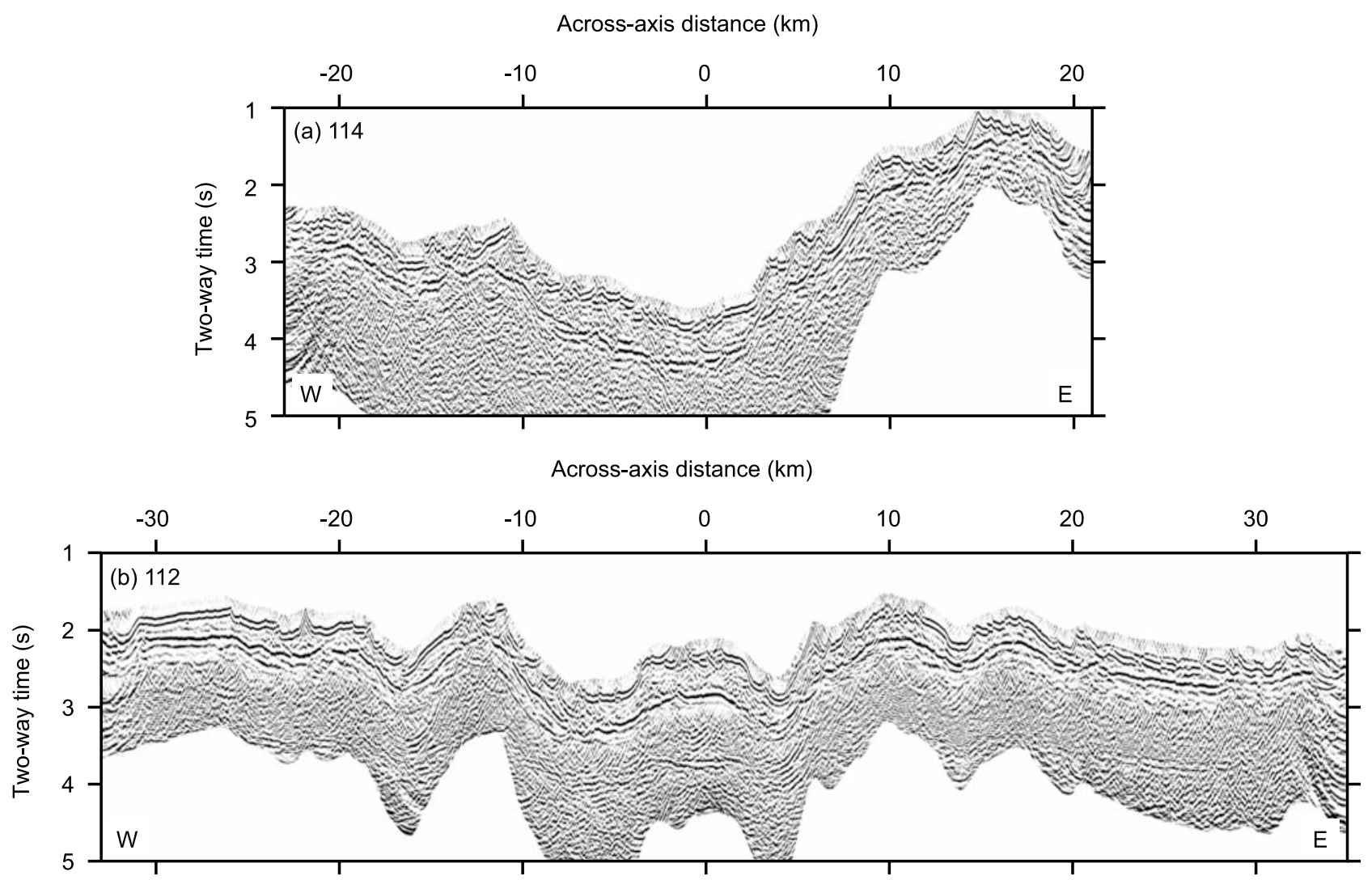

Across-axis distance $(\mathrm{km})$

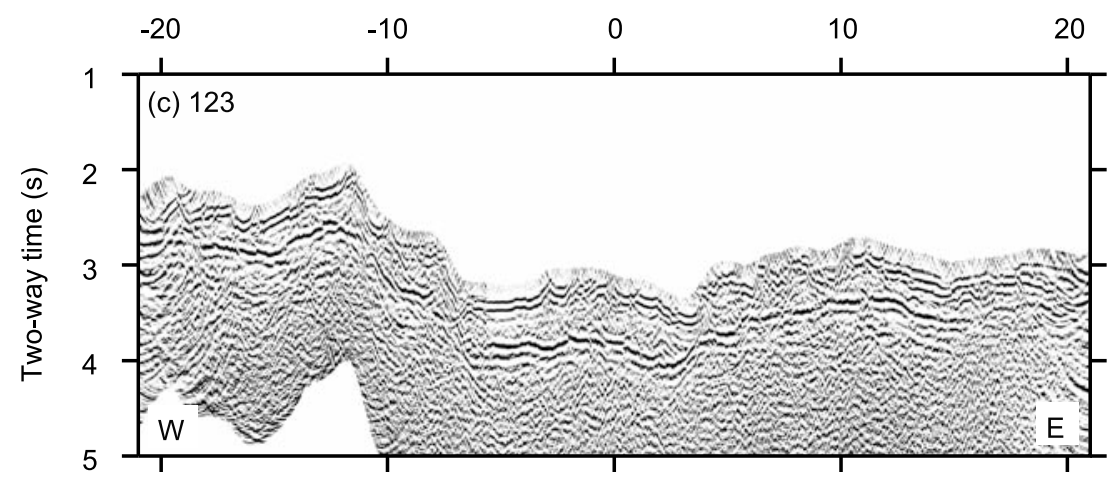

Figure 9. Time-migrated seismic section showing the across-axis variation of the seismic layer $2 \mathrm{~A} / 2 \mathrm{~B}$ boundary along profiles (a) 114, (b) 112 and (c) 123. Profile 114 runs approximately $12.7 \mathrm{~km}$ north of the Lucky Strike volcano, profile 112 crosses directly over the volcano and profile 123 is located $12.1 \mathrm{~km}$ south of the volcano. The profiles run west to east (see Figure 1 for the profile location).

value to a position in space based on its common midpoint position. Since the average line spacing $(1-2 \mathrm{~km})$ is much larger than the common midpoint spacing $(6.25 \mathrm{~m})$, the interfaces are much better sampled along profiles than between profiles. We, therefore, interpolated the data onto a $0.5 \mathrm{~km}$ by $0.5 \mathrm{~km}$ regular grid (Figure 12). This interpolation reduces the along-profile data by a factor of 80 and significantly increases the signal quality.

[35] The seismic seafloor (Figure 12a) agrees well with the seafloor estimated from multibeam bathymetry. Layer 2A (Figure 12b) follows the variation of the seafloor to first order. The average $\Delta \mathrm{TWT}_{S F-2 A}$ is $\sim 550 \mathrm{~ms}$ in the segment center and decreases to $\sim 350 \mathrm{~ms}$ off-axis. This variation is symmetric about the ridge axis. This change in $\Delta \mathrm{TWT}_{S F-2 A}$ occurs at or near the median valley bounding faults. The largest $\Delta \mathrm{TWT}_{S F-2 A}$ of $600 \mathrm{~ms}$ is observed underneath the volcanic ridge north-west of the volcano. Interestingly, $\triangle \mathrm{TWT}_{S F-2 A}$ shows ridge parallel anomalies, suggesting a link with extensional fault systems.

[36] To study long wavelength variations of layer $2 \mathrm{~A}$, we low-pass filtered $\triangle \mathrm{TWT}_{S F-2 A}$ using a Gaussian filter with a width of $10 \mathrm{~km}$ (Figure 12d). As with the unfiltered data, $\triangle \mathrm{TWT}_{S F-2 A}$ is smallest outside the median valley. The difference is on the order of $200 \mathrm{~ms}$. The local $\mathrm{TWT}_{\mathrm{SF}}$ and $\mathrm{TWT}_{2 \mathrm{~A}}$ anomaly observed below the volcano is absent from $\triangle \mathrm{TWT}_{S F-2 A}$. 

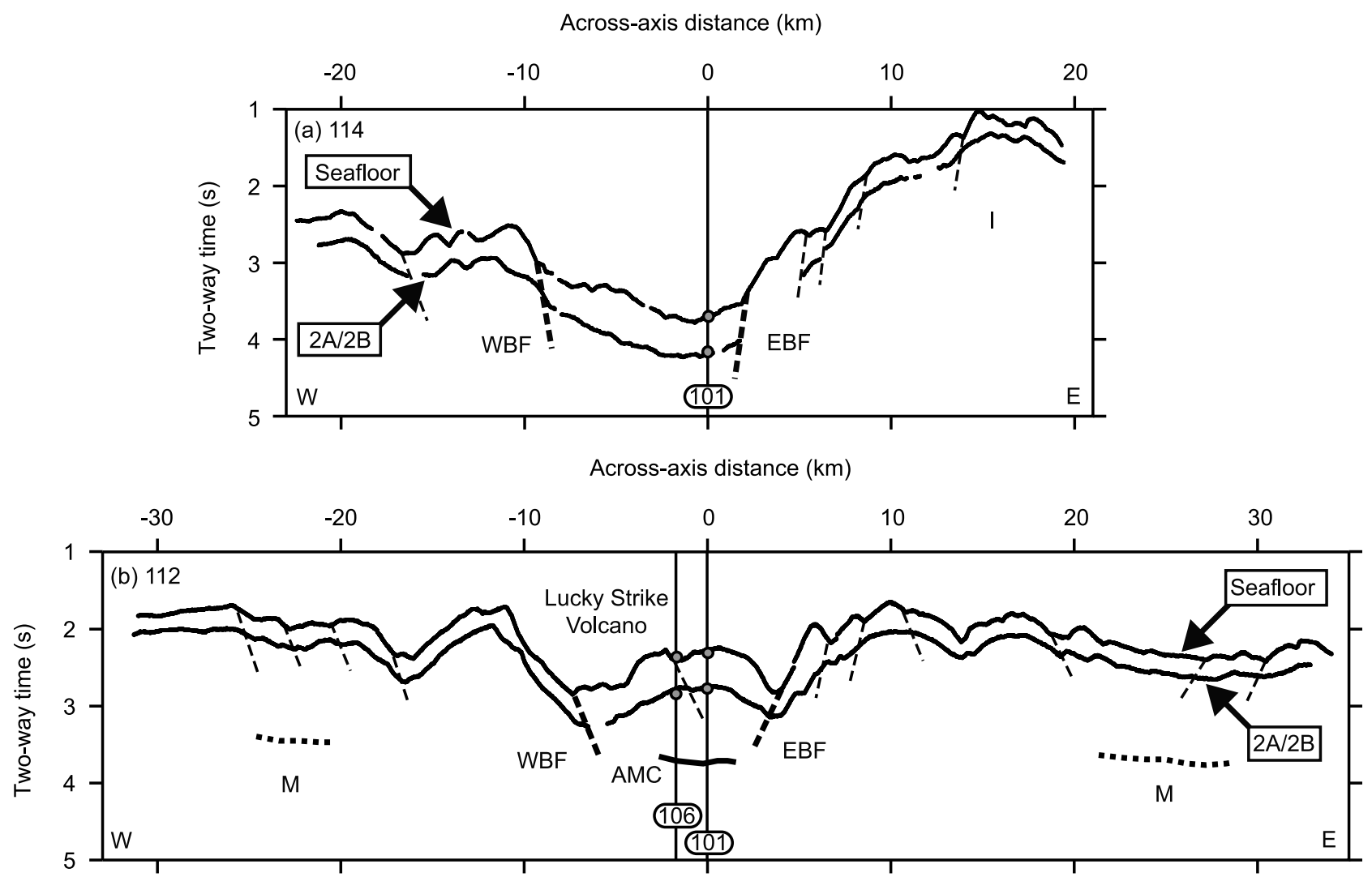

Across-axis distance $(\mathrm{km})$

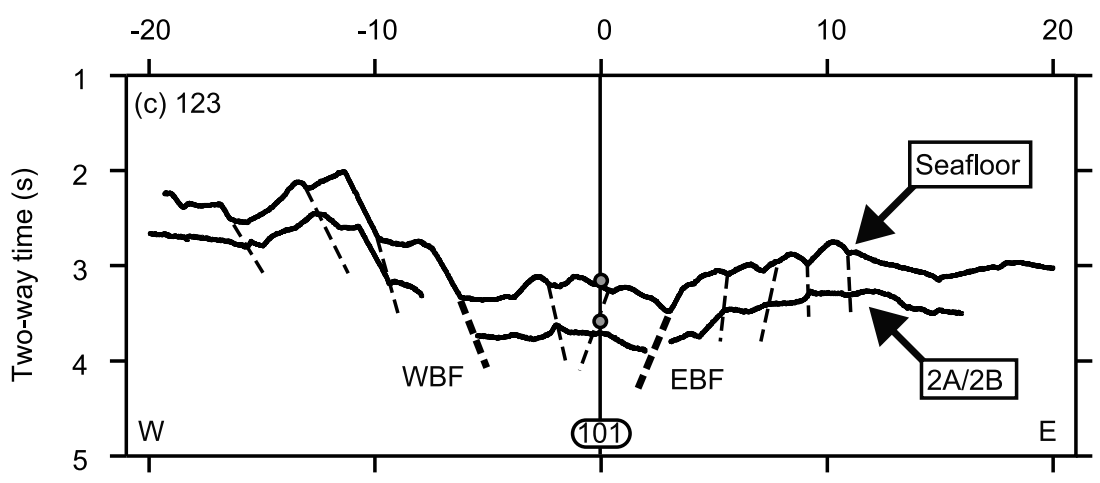

Figure 10. Interpretation of the seismic sections shown in Figure 9. The variability of the seafloor and the layer $2 \mathrm{~A} / 2 \mathrm{~B}$ boundary as well as the location of major fault systems is shown. The fault interpretation is based on offsets seen for the seafloor and the layer $2 \mathrm{~A} / 2 \mathrm{~B}$ boundary. V: Lucky Strike volcano. AMC: Axial melt lens reflection. WBF/EBF: Western/Eastern bounding fault. I: Inside corner high. M: Possible multiple reflections. The black lines mark the location of crossing profiles and the grey dots the corresponding seafloor and layer $2 \mathrm{~A} / 2 \mathrm{~B}$ picks. The profiles run west to east (see Figure 1 for the profile location).

[37] To establish a more reliable image of $\Delta \mathrm{TWT}_{S F-2 A}$, we examined the variations of $\triangle \mathrm{TWT}_{S F-2 A}$ as a function of distance from the ridge axis (Figure 13a) and of distance along the ridge axis (Figure 13b). This procedure averages out small changes in $\triangle \mathrm{TWT}_{S F-2 A}$ and highlights areas where significant changes occur.

[38] Across-axis, $\Delta \mathrm{TWT}_{S F-2 A}$ is largest in the median valley and smallest outside the median valley (Figure 13a). The variations are symmetric across the ridge axis with a slight offset to the west of the valley center. The $\Delta \mathrm{TWT}_{S F-2 A}$ variations along the ridge axis are small, leading to a small standard deviation within every bin (the grey area). This shows a symmetry of the Lucky Strike segment with respect to the ridge axis. Figure $13 \mathrm{~b}$ shows the along axis variations for comparison. $\triangle \mathrm{TWT}_{S F-2 A}$ increases toward the segment ends, but this increase of $100 \mathrm{~ms}$ is small compared to the across axis variation. Furthermore, the standard deviation is large due to the averaging of across-axis variations. Comparing with the lateral variation of the layer $2 \mathrm{~A} / 2 \mathrm{~B}$ boundary (Figure $12 \mathrm{~d}$ ) shows a $\Delta \mathrm{TWT}_{S F-2 A}$ increase toward the seg- 
Across-axis distance $(\mathrm{km})$

Along-axis distance $(\mathrm{km})$
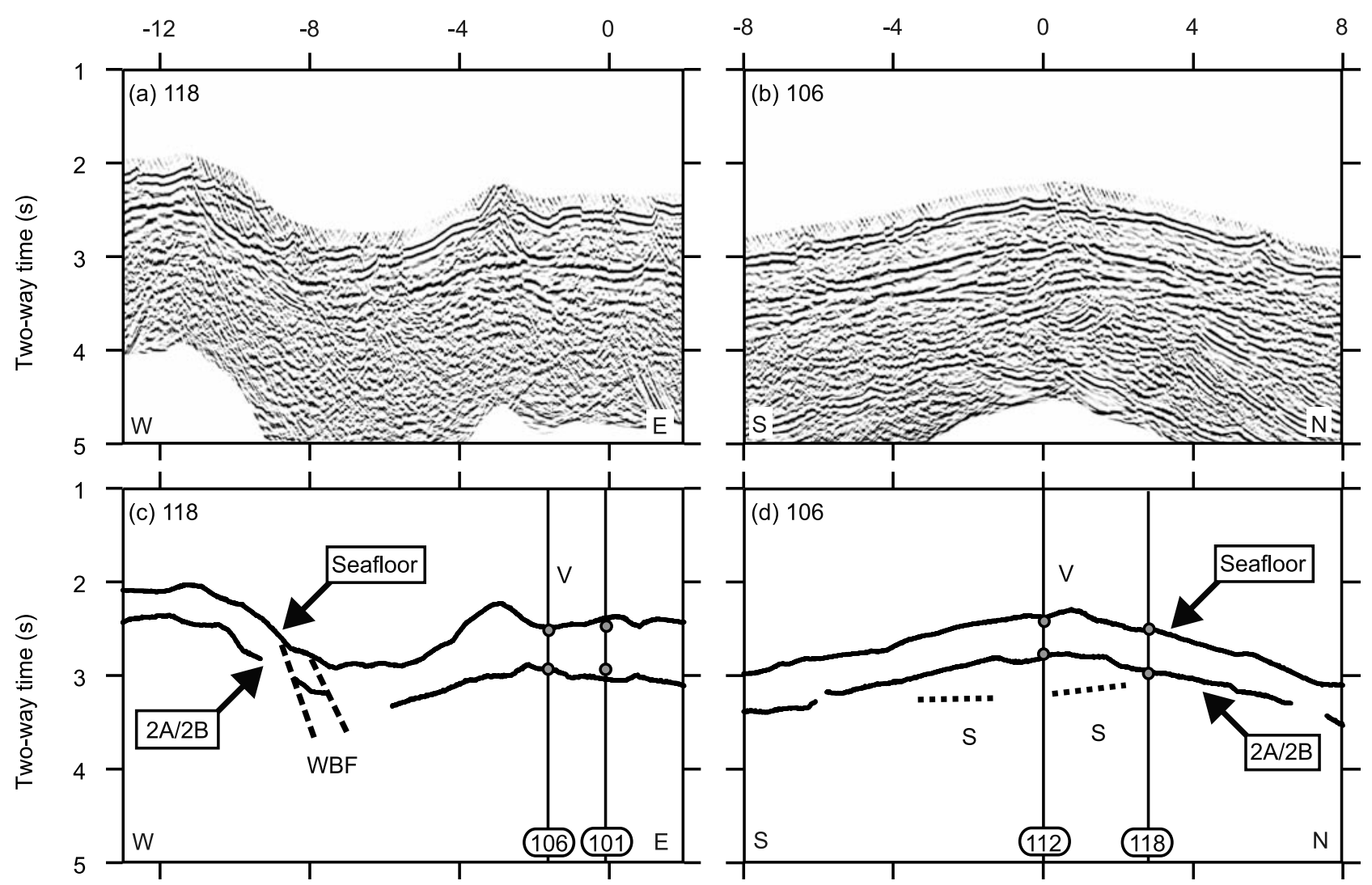

Figure 11. Comparison of along-axis and across-axis variability of the layer $2 \mathrm{~A} / 2 \mathrm{~B}$ boundary. (a and c) Profile 106 runs parallel to the ridge axis approximately $1.6 \mathrm{~km}$ west of the volcano and (b and d) profile 118 orthogonal to the ridge axis approximately $2.8 \mathrm{~km}$ north of the volcano. V: Lucky Strike volcano. S: Sub-layer 2A events. WBF: Western bounding fault. The black lines mark the location of crossing profiles (see Figure 1 for the profile location) and the grey dots the corresponding seafloor and layer $2 \mathrm{~A} / 2 \mathrm{~B}$ picks.

ment ends outside the median valley, while $\Delta \mathrm{TWT}_{S F-2 A}$ inside the median valley is approximately constant. Last, averaging $\triangle \mathrm{TWT}_{S F-2 A}$ as a function of radial distance from the volcano has shown no systematic increase in $\Delta \mathrm{TWT}_{S F-2 A}$ at the volcanic segment center.

\section{Uncertainties}

[39] In this study the lateral sampling along-profile is $6.25 \mathrm{~m}$ and the temporal sampling $4 \mathrm{~ms}$. However, the measurement uncertainty is significantly larger than the pixel size. To interpret the image of layer $2 \mathrm{~A}$, one needs to understand the quality of the picked TWT. Different error sources can influence the data differently and it is important to understand the nature and the origin of measurement errors. The biggest errors are related to: the data processing applied (especially the choice of a stacking velocity), errors in the location of streamer and source and the uncertainty in the manual picking of seismic events. The choice of the stacking velocity profile introduces an uncertainty of $\sim 60 \mathrm{~ms}$. Here, we will analyze errors associated with the use of a two-dimensional processing geometry and the manual picking by comparing TWT on crossing profiles.
[40] The data were acquired along a grid of lines with lines running approximately from north to south and from west to east. At the crossing points of those lines the same position is thus remeasured (Figure 14a). Subtracting the TWT picked at these points yields a residual. Treating the residuals as one ensemble, we estimate the mean and the standard deviation. The mean is non-zero for both the seafloor and layer $2 \mathrm{~A}$ events (Figures $14 \mathrm{~b}$ and $14 \mathrm{c}$ ), but the mean residuals are smaller than one standard deviation. The standard deviation can be used to estimate the pick uncertainty (the cross-over error), which is $\sim 50 \mathrm{~ms}$ for the seafloor event and $\sim 75 \mathrm{~ms}$ for the layer $2 \mathrm{~A}$ event.

[41] Taking into account the approximations made during processing and the choice of the stacking velocity, we estimate the total uncertainty for a single $\Delta \mathrm{TWT}_{S F-2 A}$ measurement to be $\sim 110 \mathrm{~ms}$.

\section{Thickness or Velocity Variations}

[42] We want to convert the observed TWT to depth. Depth migrating the TWT image is not possible, since it requires the knowledge of the subsurface velocity structure. A TWT variation of a seismic interface can be caused by 

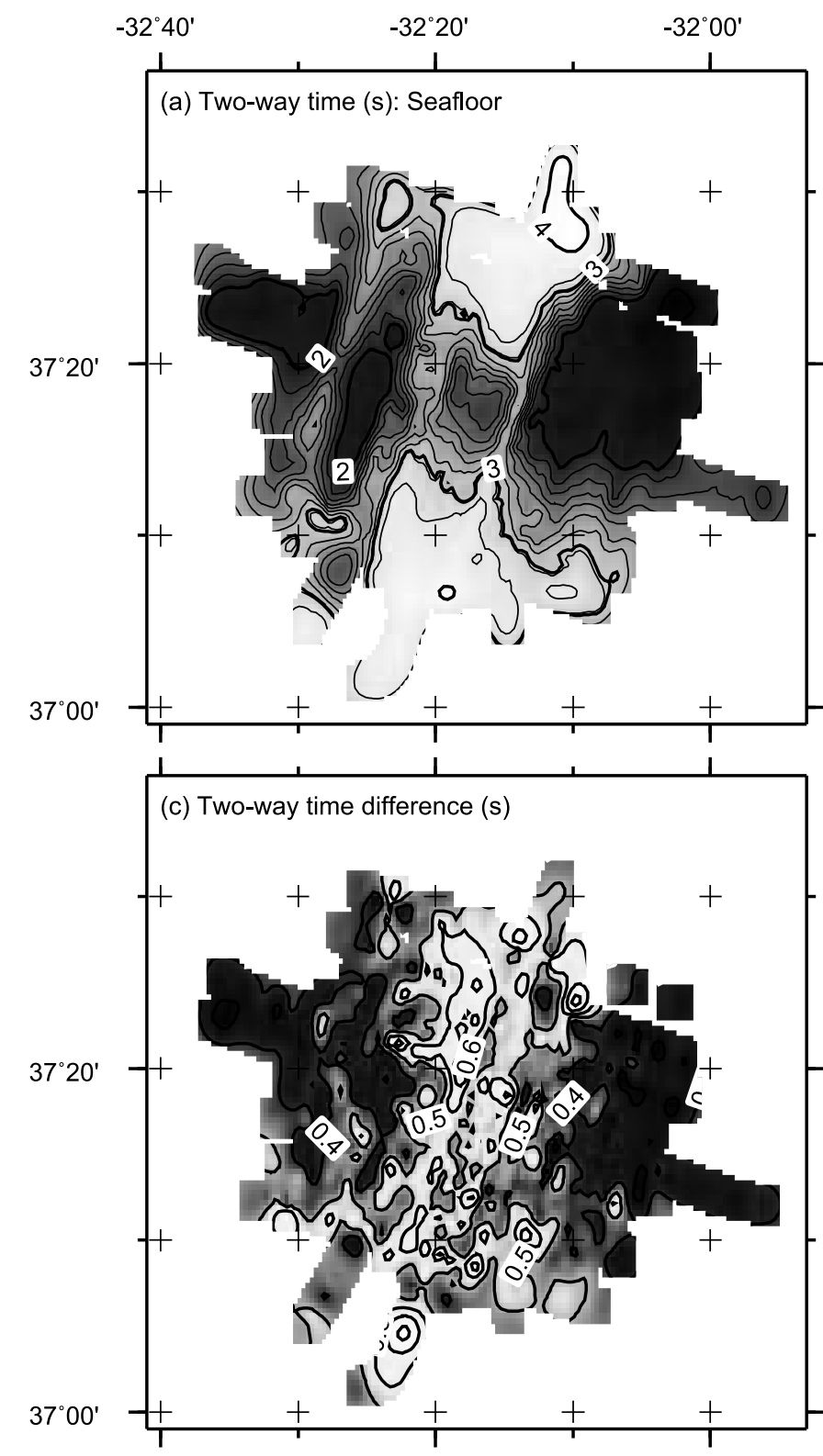

$-32^{\circ} 40^{\prime}$

$-32^{\circ} 20^{\prime}$

$-32^{\circ} 00^{\prime}$

(b) Two-way time (s): 2A/2B

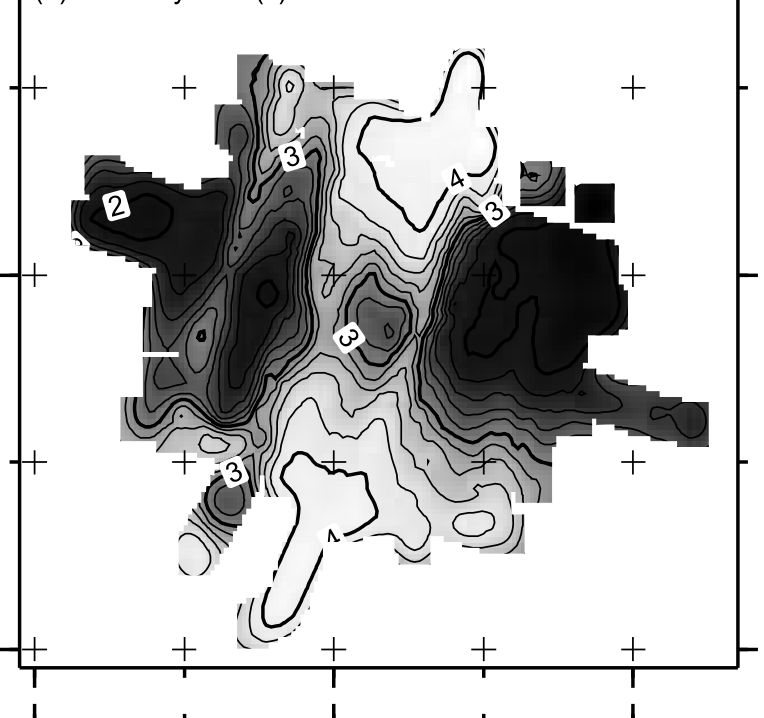

(d) Filtered two-way time difference (s)

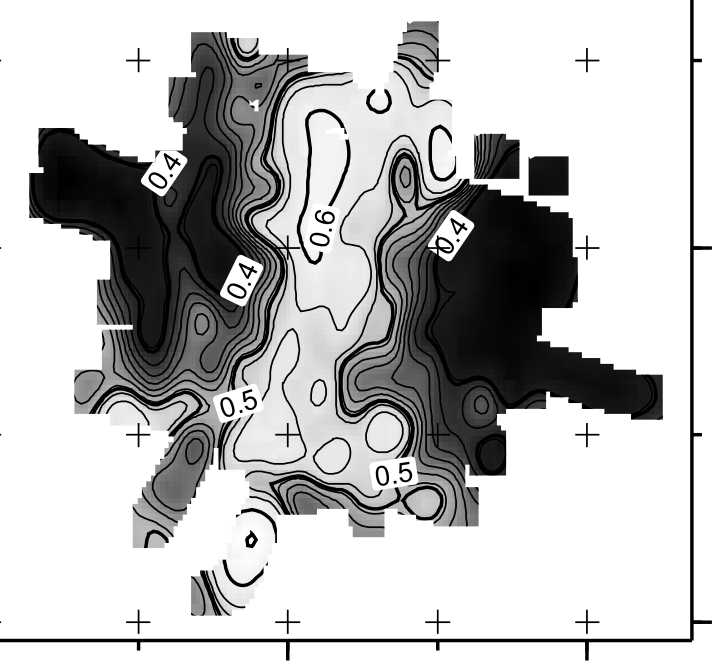

Figure 12. Lateral TWT variability. The TWT picks for the 24 studied profiles were gridded to construct a three-dimensional image of the layer $2 \mathrm{~A}$ variation. Image of (a) $\mathrm{TWT}_{\mathrm{SF}}$ and (b) $\mathrm{TWT}_{2 \mathrm{~A}}$ (c) Unfiltered $\Delta \mathrm{TWT}_{S F-2 A}$. (d) Low-pass filtered $\Delta \mathrm{TWT}_{S F-2 A}$ using a Gaussian filter with a filter width of $10 \mathrm{~km}$.

both a change in seismic velocity and/or a change in interface depth. Since no high-resolution velocity model of the near-surface exists, we chose to explore two end-member models having a constant velocity and variable thickness layer $2 \mathrm{~A}$ or a constant thickness and variable velocity layer 2A. This allows us to assess whether the two models are consistent with our observations. We use the code of Hobro et al. [2003] to convert the observed normal-incidence TWT to velocity or depth. Since normal-incidence data cannot be used to simultaneously constrain interface depth and velocity, we fix one of the parameters and invert for the other. Smoothness regularization inhibits abrupt variations of velocity or depth and respects the uncertainty of the TWT observations. A similar result could be obtained by linking
TWT to velocity or depth for every TWT pick and smoothing the resulting image.

[43] Model I assumes an average layer 2A velocity of $2.5 \mathrm{~km} / \mathrm{s}$ and a variable layer $2 \mathrm{~A}$ thickness (Figure 15b). Model II assumes a layer 2A thickness of $650 \mathrm{~m}$ and a variable layer $2 \mathrm{~A}$ velocity (Figure 15c). While model I requires a layer $2 \mathrm{~A}$ thickness decrease of $350 \mathrm{~m}$ over a distance of $20 \mathrm{~km}$ from the ridge axis, model II requires a velocity increase on the order of $1-1.5 \mathrm{~km} / \mathrm{s}$ to explain the same observations. Along the ridge axis, we observe very little variability for the two models. For the constant velocity model I layer $2 \mathrm{~A}$ thickness varies by less than $0.1 \mathrm{~km}$ along the central $40 \mathrm{~km}$ of the ridge segment. For the constant layer $2 \mathrm{~A}$ thickness model II along-axis layer $2 \mathrm{~A}$ velocity 

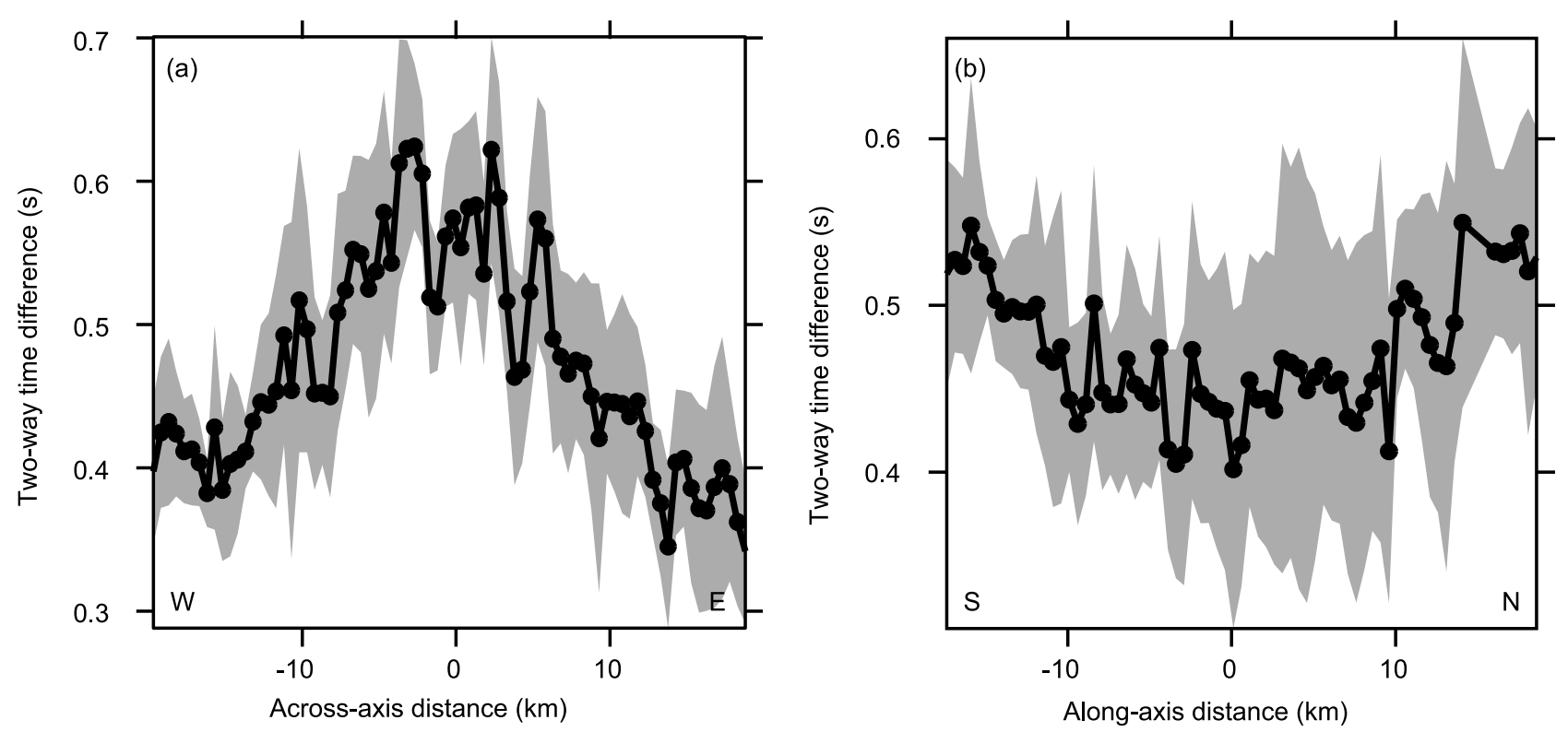

Figure 13. Two-way time difference $\Delta \mathrm{TWT}_{S F-2 A}$ (a) as a function of across-axis distance and (b) as function of along-axis distance. The $\triangle \mathrm{TWT}_{S F-2 A}$ values along all profiles were sorted with respect to along- or across-axis distance. Next, the data were binned and averaged to obtain a mean $\Delta \mathrm{TWT}_{S F-2 A}$ value (black line) and standard deviation (grey area) for every along- and across-axis bin, respectively.

varies by less than $0.5 \mathrm{~km} / \mathrm{s}$ over the central $40 \mathrm{~km}$ of the ridge segment.

[44] Both models I and II can explain the observed normalincidence TWT. Based on the normal-incidence observations alone it is not possible to differentiate between the two scenarios. For comparison with the two scenarios presented here, we show upper crustal velocities from a coincident seismic refraction survey [Seher et al., 2010a]. We note that the layer $2 \mathrm{~A}$ velocities in the tomography model are poorly constrained because of the geometry of the raypaths. However, the tomography model (Figure 15d) shows a comparable velocity increase of $\sim 1 \mathrm{~km} / \mathrm{s}$ with distance from the ridge axis.

\section{Discussion}

[45] The key observations made in this study are: an almost constant $\triangle \mathrm{TWT}_{S F-2 A}$ of $\sim 550 \mathrm{~ms}$ along the central $40-45 \mathrm{~km}$ long portion of the ridge segment and a $\triangle \mathrm{TWT}_{S F-2 A}$ decrease of $\sim 200 \mathrm{~ms}$ across the median valley bounding faults. These observations are symmetric with respect to the ridge axis; $\triangle \mathrm{TWT}_{S F-2 A}$ is almost constant throughout the median valley and the $\Delta \mathrm{TWT}_{S F-2 A}$ decrease occurs at both the eastern and western bounding faults. Furthermore, recent volcanic edifices cause only minor variations in $\triangle \mathrm{TWT}_{S F-2 A}$. The $\Delta \mathrm{TWT}_{S F-2 A}$ decrease across the median valley bounding faults is significantly larger than the uncertainty of the unfiltered $\Delta \mathrm{TWT}_{S F-2 A}$. This uncertainty amounts to $\sim 110 \mathrm{~ms}$. However, the filtered image is more reliable than the uncertainty given above.

[46] Comparing our seismic images with images from seismic experiments where imaging conditions and acquisition parameters were better (e.g., smoother seafloor and smaller shot spacing), the seismic layer $2 \mathrm{~A}$ boundary in our images appears more continuous. This continuous appearance may be linked to along-profile "smearing" due to prestack trace interpolation and DMO correction.

[47] The observed normal incidence $\mathrm{TWT}_{2 \mathrm{~A}}$ may be explained using one of two end-member models for the structure of layer 2A (Figure 15). In the first scenario a constant velocity layer $2 \mathrm{~A}$ is created at the ridge axis and is thinned by $350 \mathrm{~m}$ as the crust is rifted off-axis. In the second scenario a constant thickness layer $2 \mathrm{~A}$ is created at the ridge axis. As the crust is rifted off-axis, layer $2 \mathrm{~A}$ velocities increase by $1-1.5 \mathrm{~km} / \mathrm{s}$. TWT modeling for a shot gathers on the ridge axis and on the bounding walls indicates a velocity increase of $\sim 1 \mathrm{~km} / \mathrm{s}$ (Figure 3 ). A coincident seismic refraction survey [Seher et al., 2010a] has shown a similar upper crustal velocity increase of $\sim 1 \mathrm{~km} / \mathrm{s}$. These two independent observations showing an upper crustal velocity increase imply that most the observed $\Delta \mathrm{TWT}_{S F-2 A}$ decrease is accommodated by an off-axis velocity increase and only a small part of the $\triangle \mathrm{TWT}_{S F-2 A}$ decrease may be caused by layer 2A thinning. Furthermore, Hussenoeder et al. [2002b] observe a similar velocity increase for the $\mathrm{OH}-1$ segment. Applying the porosity-velocity relationship by Carlson and Herrick [1990] this velocity increase can be explained by a porosity decrease of $\sim 8 \%$.

[48] There are three possible explanations for the observed velocity increase and porosity decrease causing the layer 2A/2B transition: (1) A lithologic boundary between extrusive and intrusive basalt, (2) an alteration front below which pores have been filled with alteration products, or (3) a porosity limit below which pores are closed by the overburden pressure. It is likely that a single mechanism may not be able to explain the observations and hence one or more processes might be occurring synchronously or successively. 

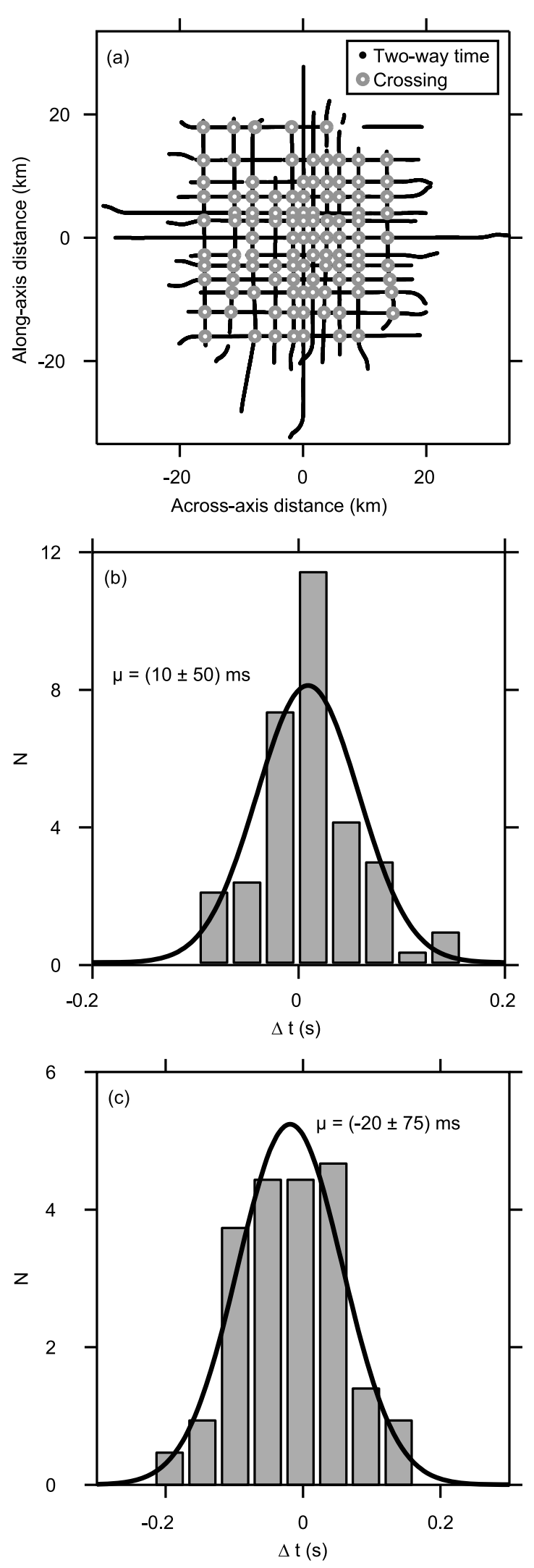

Therefore, it is important to address whether a mechanism dominates in different parts of the Lucky Strike segment.

[49] It is particularly interesting to know if there is a link between the constant thickness layer $2 \mathrm{~A}$ and a constant thickness extrusive layer inside the median valley. How can the constant layer $2 \mathrm{~A}$ thickness inside the median valley be explained? Assuming that hypothesis 1 is correct and the boundary between layers $2 \mathrm{~A}$ and $2 \mathrm{~B}$ corresponds to the boundary between extrusive and intrusive basalt, dike injection events and a similar thickness of lava flows are required along the length of the segment. The seafloor morphology in the Lucky Strike segment shows that volcanism is not concentrated at the segment center, but exists throughout the median valley. Dike injection events over large distances have been observed in Iceland [Buck et al., 2006], Ethiopia [Wright et al., 2006; Doubre et al., 2007] and at Axial Volcano on the Juan de Fuca Ridge [Dziak and Fox, 1999]. Furthermore, there is evidence for a recent diking episode in the Lucky Strike segment [Dziak et al., 2004] and for volcanic morphologies along the whole length of the median valley [Parson et al., 2000]. No thickening of layer $2 \mathrm{~A}$ is observed outside the median valley, which indicates crustal accretion is limited to the median valley. This agrees well with the well documented fact that axial valley walls typically have magnetic anomaly ages of $700 \mathrm{ka}$ or more [Miranda et al., 2005]. Last, if the bottom of layer $2 \mathrm{~A}$ corresponded to the limit between extrusive and intrusive basalt, this would explain a slightly elevated $\triangle \mathrm{TWT}_{S F-2 A}$ underneath the volcano and the western volcanic ridge due to the greater abundance of extrusive lava.

[50] This hypothesis agrees with observations for the $\mathrm{OH}-1$ segment at $35^{\circ} \mathrm{N}$. Hussenoeder et al. [2002b] observe a regular layer $2 \mathrm{~A}$ within the rift valley and conclude that most of the extrusive section is built on the inner valley floor through a pattern of lava deposition, which is interrupted during tectonically dominated periods. Hussenoeder et al. [2002b] further observe thickening of layer 2A toward the Oceanographer fracture zone, which they interpret as result of along-axis magma transport. Here, we observe a small increase in $\Delta \mathrm{TWT}_{S F-2 A}$ toward the southern nodal basin, but do not require a significant thickness decrease.

[51] For ridges with an axial high Buck et al. [1997] predict that a deep magma chamber would be linked to a thick extrusive layer. For the Lucky Strike segment both a deep axial magma chamber [Singh et al., 2006; Combier, 2007] and a thick layer $2 \mathrm{~A}$ have been observed. If one ignores the influence of the wide median valley, this implies

Figure 14. TWT uncertainty estimate based on crossing profiles. When two seismic lines cross, approximately the same seismic measurement is repeated. Subtracting TWT measurements on different seismic profiles but within half a common midpoint spacing $(3.25 \mathrm{~m})$ of each other is used to estimate a TWT residual. (a) The positions of all seafloor TWT picks are shown as black points. The crossings used to estimate the residuals for the seafloor reflection are highlighted as grey points. By assuming those points to sample the same uncertainty distribution one can estimate mean and standard deviation for (b) $\mathrm{TWT}_{\mathrm{SF}}$ and (c) $\mathrm{TWT}_{2 \mathrm{~A}}$. The number of residuals per bin was normalized to unit area to estimate the Gaussian probability distribution(black line). 


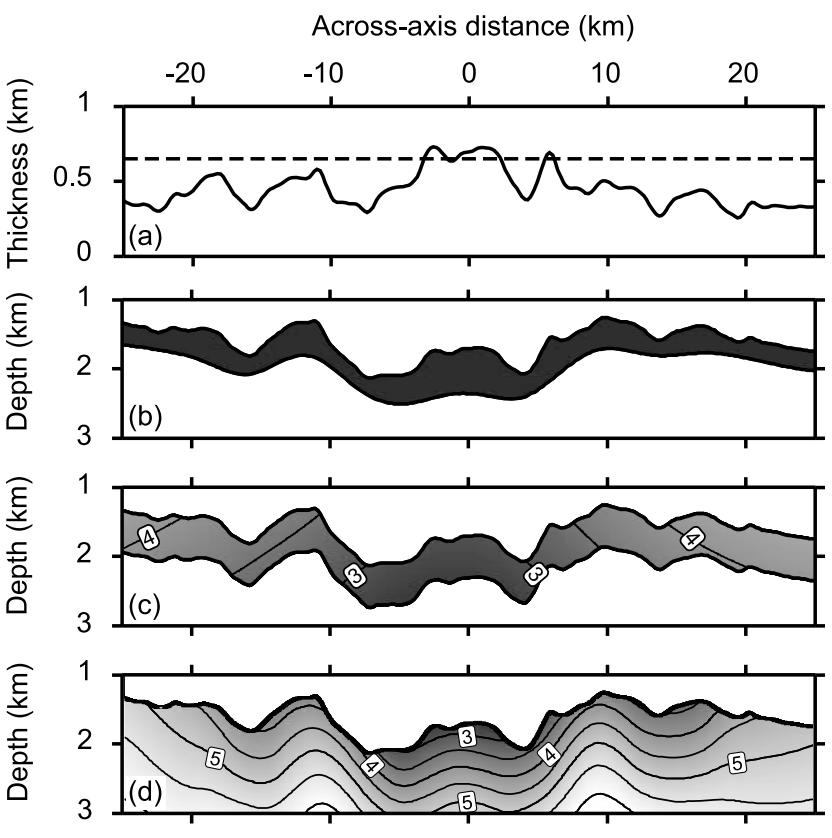

Figure 15. Constant layer $2 \mathrm{~A}$ velocity and constant layer $2 \mathrm{~A}$ thickness scenarios explaining the observed $\Delta \mathrm{TWT}_{S F-2 A}$ decrease. (a) Comparison of the layer $2 \mathrm{~A}$ thickness for the two scenarios. (b) A constant velocity layer $2 \mathrm{~A}$ thins with distance from the ridge axis. (c) Constant thickness layer 2A. The velocity increases with distance from the ridge axis. (d) The velocity structure from a coincident wide-angle seismic tomography study [Seher et al., 2010a]. The labels in Figures $15 \mathrm{c}$ and $15 \mathrm{~d}$ mark isovelocity contours.

that seismic layer 2A may be closely linked to the extrusive layer.

[52] A slightly thicker layer $2 \mathrm{~A}$ underneath the Lucky Strike volcano compared to the median valley may be caused by recent volcanism in the segment center. Explaining the off-axis velocity increase as a lithologic effect is difficult, since it requires a change from high-porosity to low-porosity pillow lava or a lower number of eruptive diking events. The latter effect could be caused by a magma-rich period, i.e. a shallower magma chamber and a higher spreading rate. However, no evidence for a dramatic change in spreading rate exists in this region. The spreading rate has been $\sim 2.2 \mathrm{~cm} / \mathrm{a}$ for the last $7 \mathrm{Ma}$, which corresponds to an off-axis distance of $\sim 77 \mathrm{~km}$ [Cannat et al., 1999].

[53] Hypothesis 2 links the layer 2A/2B boundary to an alteration front in the upper crust. Explaining layer $2 \mathrm{~A}$ thickness as an alteration boundary requires a second process creating the porosity in zero age crust (e.g., accretion or extension), which is subsequently altered by hydrothermal circulation. For freshly emplaced basalt all the pore spaces defining the porosity are still open. Thin cracks are then quickly sealed with alteration products near the accretion center [Wilkens et al., 1991; Shaw, 1994] possibly creating a constant thickness layer 2A inside the median valley, while thick cracks remain open. With increasing distance from the accretion center, hydrothermal mineralization gradually fills those larger voids [Shaw, 1994; Carlson, 1998]. As the crust ages, the porosity limit defining the bottom of layer $2 \mathrm{~A}$ becomes shallower and layer $2 \mathrm{~A}$ velocities increase, as cracks below the alteration front are filled by hydrothermal metamorphism.

[54] For the OH-1 segment Hussenoeder et al. [2002b] find evidence for off-axis hydrothermal circulation. First, they observe an off-axis velocity increase, which they interpret as porosity reduction due to hydrothermal cementation. Second, the models indicate a thinning of the layer $2 \mathrm{~A} / 2 \mathrm{~B}$ transition, which may result from enhanced hydrothermal mineralization in the zone of mixed dikes and extrusives. Again, both these observations are consistent with the off-axis velocity increase that we suggest for the Lucky Strike segment.

[55] Interestingly, the abrupt change in $\Delta \mathrm{TWT}_{S F-2 A}$ occurs at the median valley bounding faults, where the valley floor is uplifted to the ridge shoulders. This may suggest that hydrothermal activity is enhanced when faults become active. The bounding faults may serve as recharge zones for hydrothermal circulation, facilitating secondary mineralization that may cause a layer $2 \mathrm{~A}$ porosity decrease and velocity increase.

[56] Hypothesis 3 interprets the bottom of layer $2 \mathrm{~A}$ as a porosity threshold defined by the closure of pore spaces by the effect of the confining pressure. As for the alteration front the pore space collapse mechanism requires a second process creating the porosity. The collapse of pore spaces under a certain load explains the constant layer $2 \mathrm{~A}$ thickness within the median valley. However, this hypothesis also suggests that layer $2 \mathrm{~A}$ thickness should be similar on all different ridge segments, which is not the case.

[57] Tectonic stretching along large normal faults may cause a small amount of off-axis layer $2 \mathrm{~A}$ thinning. It is more difficult to explain the off-axis layer $2 \mathrm{~A}$ velocity increase as effect of a porosity threshold. Decreasing porosity and increasing the velocity requires an increase in confining pressure or a decrease in pore pressure; the shallower water depth could cause a slight velocity decrease [Christensen, 1984], but a velocity increase is observed here. However, similarly to the idea of crack closure at depth through a pressure increase, one can imagine that an off-axis increase in confining pressure may lead to further pore space collapse, a lateral velocity decrease and velocity increase. While the extensional stresses inside the median valley are accommodated by a large number of faults, fractures and fissures, off-axis strain may be localized along large normal faults. One can imagine an associated change of the stress field and associated confining pressure at the median valley bounding faults, which leads to a porosity decrease and velocity increase with off-axis distance.

\section{Conclusions}

[58] Extensive analysis of seismic reflection data recorded in the Lucky Strike segment allows new observations about the nature of the layer $2 \mathrm{~A} / 2 \mathrm{~B}$ transition. Inside the median valley $\triangle \mathrm{TWT}_{S F-2 A}$ is $550 \mathrm{~ms}$, which corresponds to a layer $2 \mathrm{~A}$ thickness $\sim 600 \mathrm{~m}$. We observe a significant difference of $\triangle \mathrm{TWT}_{S F-2 A}$ on- and off-axis. $\Delta \mathrm{TWT}_{S F-2 A}$ decreases by $\sim 150 \mathrm{~ms}$ to $200 \mathrm{~ms}$, which is likely caused by a velocity increase of $\sim 1 \mathrm{~km} / \mathrm{s}$ over a distance of $\sim 20 \mathrm{~km}$ from the ridge axis. 
[59] In our opinion the most likely explanation for the uniform layer $2 \mathrm{~A}$ thickness on the ridge axis are magmatic processes, i.e. the lithologic lava/dike boundary. On the ridge flanks we observe extensive faulting coincident with an abrupt change in layer 2A properties, which may indicate that hydrothermal activity is enhanced when the large median bounding faults become active. Away from the ridge axis hydrothermal alteration is the most plausible mechanisms explaining the off-axis layer $2 \mathrm{~A}$ velocity increase.

[60] Acknowledgments. This work was made possible by funding from the EU Marie Curie RTN MOMARNET, the Institut de Physique du Globe de Paris, CNRS/INSU, Ifremer, and the state of Portugal. Crew and captain of the French research vessel N/O L'Atalante helped to make this project a success. Last, this manuscript profited greatly from discussions with Javier Escartin, Juan-Pablo Canales, William Wilcock and Ingo Grevemeyer. We thank the reviewers Suzanne Carbotte and Ingo Grevemeyer for their suggestions that helped us to greatly improve our work. The Generic Mapping Tools, Seismic Unix and Pardigm Focus were used for data processing and visualization.

\section{References}

Avedik, F., V. Renard, J. Allenou, and B. Morvan (1993), "Single bubble" air-gun array for deep exploration, Geophysics, 58(3), 366-382, doi:10.1190/1.1443420.

Avedik, F., V. Hirn, A. Renard, R. Nicolich, J. Olivet, and M. Sachapazi (1996), "Single-bubble" marine source offers new perspectives for lithospheric exploration, Tectonophysics, 267, 57-71, doi:10.1016/S00401951(96)00112-6.

Barclay, A., D. Toomey, and S. Solomon (1998), Seismic structure and crustal magmatism at the Mid-Atlantic Ridge, $35^{\circ} \mathrm{N}$, J. Geophys. Res., 103(B8), 17,827-17,844, doi:10.1029/98JB01275.

Becker, K., and A. Fisher (2000), Permeability of upper oceanic basement on the eastern flank of the Juan de Fuca ridge determined with drill-string packer experiments, J. Geophys. Res., 105(B1), 897-912, doi:10.1029/ 1999JB900250.

Becker, K., et al. (1982), In situ electrical resistivity and bulk porosity of the oceanic crust Cost Rica Rift, Nature, 300, 594-598, doi:10.1038/ 300594a0.

Becker, K., E. Davis, F. Spiess, and C. deMoustier (2004), Temperature and video logs from the upper oceanic crust, holes 504B and 896(a), Costa Rica Rift flank: Implications for the permeability of upper oceanic crust, Earth Planet. Sci. Lett., 222,881-896, doi:10.1016/j. eps1.2004.03.033.

Blacic, T. M., G. Ito, J. P. Canales, R. S. Detrick, and J. Sinton (2004), Constructing the crust along the Galapagos Spreading Center 91.3 ${ }^{\circ}$ $95.5^{\circ} \mathrm{W}$ : Correlation of seismic layer $2 \mathrm{~A}$ with axial magma lens and topographic characteristics, J. Geophys. Res., 109, B10310, doi:10.1029/ 2004JB003066.

Black, J., K. Schleicher, and L. Zhang (1993), True-amplitude imaging and dip moveout, Geophysics, 58(1), 47-66, doi:10.1190/1.1443351.

Boudier, F., A. Nicolas, B. Ildefonseand, and D. Jousselin (1997), EPR microplates, a model for the Oman ophiolite, Terra Nova, 9, 79-82, doi:10.1111/j.1365-3121.1997.tb00007.x.

Bratt, S., and G. Purdy (1984), Structure and variability of oceanic crust on the flanks of the East Pacific Rise between $11^{\circ}$ and $13^{\circ} \mathrm{N}, J$. Geophys. Res., 89(B7), 6111-6125, doi:10.1029/JB089iB07p06111.

Buck, W. R., S. M. Carbotte, and C. Mutter (1997), Controls on extrusion at mid-ocean ridges, Geology, 25(10), 935-938, doi:10.1130/0091-7613 (1997)025<0935:COEAMO >2.3.CO;2.

Buck, W. R., P. Einarsson, and B. Brandsdóttir (2006), Tectonic stress and magma chamber size as controls on dike propagation: Constraints from the 1975-1984 Krafla rifting episode, J. Geophys. Res., 111, B12404, doi:10.1029/2005JB003879.

Canales, J. P., R. Detrick, S. Carbotte, G. Kent, J. Diebold, A. Harding, J. Babcok, M. Nedimović, and E. van Ark (2005), Upper crustal structure and axial topography at intermediate-spreading ridges: Seismic constraints from the southern Juan de Fuca Ridge, J. Geophys. Res., 110, B12104, doi:10.1029/2005JB003630.

Cannat, M., et al. (1999), Mid-Atlantic Ridge-Azores hotspot interactions: Along-axis migration of a hotspot-derived event of enhanced magmatism
10 to 4 Ma ago, Earth Planet. Sci. Lett., 173, 257-269, doi:10.1016/ S0012-821X(99)00234-4.

Carbotte, S., and D. Scheirer (2004), Variability of ocean crustal structure created along the global mid-ocean ridge, in Hydrogeology of the Oceanic Lithosphere, edited by E. E. Davis and H. Elderfield, pp. 59107, Cambridge Univ. Press, Cambridge, U. K.

Carlson, R. (1998), Seismic velocities in the uppermost oceanic crust: Age dependence and the fate of layer 2A, J. Geophys. Res., 103(B4), 70697077, doi:10.1029/97JB03577.

Carlson, R., and C. Herrick (1990), Densities and porosities in the oceanic crust and their variations with depth and age, J. Geophys. Res., 95(B6), 9153-9170, doi:10.1029/JB095iB06p09153.

Carlson, R., and R. Jacobsen (1994), Comment on "Upper crustal structure as a function of plate age" by Robert Houtz and John Ewing, J. Geophys. Res., 99(B2), 3135-3138, doi:10.1029/93JB03013.

Chapman, N., and D. Hannay (1994), Seismic velocities of upper oceanic crust, Geophys. Res. Lett., 21(21), 2315-2318, doi:10.1029/94GL01690.

Christensen, N. (1984), Pore pressure and oceanic crustal seismic structure, Geophys. J. R. Astron. Soc., 79, 411-423.

Christeson, G., G. Kent, G. Purdy, and R. Detrick (1996), Extrusive thickness variability at the East Pacific Rise, $9^{\circ}-10^{\circ} \mathrm{N}$ : Constraints from seismic techniques, J. Geophys. Res., 101(B2), 2859-2873, doi:10.1029/ 95JB03212.

Christeson, G., K. McIntosh, and J. Karson (2007), Inconsistent correlation of layer 2A and lava layer thickness in oceanic crust, Nature, 445, 418421, doi: $10.1038 /$ nature05517.

Collier, J., and S. Singh (1998), Poisson's ratio structure of young oceanic crust, J. Geophys. Res., 103(B9), 20,981-20,996, doi:10.1029/ 98JB01980.

Combier, V. (2007), Mid-ocean ridge processes: Insights from 3D reflection seismics at the $9^{\circ} \mathrm{N}$ OSC on the East Pacific Rise, and the Lucky Strike Volcano on the Mid-Atlantic Ridge, Ph.D. thesis, Inst. de Phys. du Globe de Paris, Paris.

Cudrak, C., and R. Clowes (1993), Crust structure of Endeavour Ridge Segment, Juan de Fuca Ridge, from a detailed seismic refraction survey, J. Geophys. Res., 98(B4), 6329-6349, doi:10.1029/92JB02860.

Day, A., C. Peirce, and M. Sinha (2001), Three-dimensional crustal structure and magma chamber geometry at the intermediate-spreading, back-arc Valu Fa Ridge, Lau Basin-Results of a wide-angle seismic tomographic inversion, Geophys. J. Int., 146, 31-52, doi:10.1046/j.0956-540x.2001.01446.x.

Detrick, R., H. Needham, and V. Renard (1995), Gravity anomalies and crustal thickness variations along the Mid-Atlantic Ridge between $33^{\circ}$ $\mathrm{N}$ and $40^{\circ} \mathrm{N}$, J. Geophys. Res., 100(B3), 3767-3787, doi:10.1029/ 94JB02649.

Doubre, C., I. Manighetti, C. Dorbath, L. Dorbath, E. Jacques, and J. C. Delmond (2007), Crustal structure and magmato-tectonic processes in an active rift (Asal-Ghoubbet, Afar, East Africa): 1. Insights from a 5-month seismological experiment, J. Geophys. Res., 112, B05405, doi:10.1029/2005JB003940.

Dziak, R., and C. Fox (1999), The January 1998 earthquake swarm at Axial Volcano, Juan de Fuca Ridge: Hydroacoustic evidence of seafloor volcanic activity, Geophys. Res. Lett., 26(23), 3429-3432, doi:10.1029/ 1999GL002332.

Dziak, R., D. Smith, D. Bohnenstiehl, C. Fox, D. Desbruyeres, H. Matsumoto, M. Tolsoty, and D. Fornari (2004), Evidence of a recent magma dike intrusion at the slow spreading Lucky Strike segment, Mid-Atlantic Ridge, J. Geophys. Res., 109, B12102, doi:10.1029/2004JB003141.

Escartín, J., R. García, O. Delaunoy, J. Ferrer, N. Gracias, A. Elibol, X. Cufi, L. N. D. Fornari, S. Humphris, and J. Renard (2008), Globally aligned photomosaic of the Lucky Strike hydrothermal vent field (Mid-Atlantic Ridge, $37^{\circ} 50^{\prime} \mathrm{N}$ ): Release of georeferenced data, mosaic construction, and viewing software, Geochem. Geophys. Geosyst., 9, Q12009, doi:10.1029/ $2008 \mathrm{GC} 002204$.

Fouquet, Y., H. Ondréas, J.-L. Charlou, J.-P. Donval, J. Radford-Knoery, I. Costa, N. Lourenço, and M. Tivey (1995), Atlantic lava lakes and hot vents, Nature, 377, 201, doi:10.1038/377201a0.

Grevemeyer, I., and A. Bartetzko (2004), Hydrothermal aging of oceanic crust: inferences from seismic refraction and borehole studies, in Hydrogeology of the Oceanic Lithosphere, edited by E. E. Davis and H. Elderfield, pp. 128150, Cambridge Univ. Press, Cambridge, U. K.

Grevemeyer, I., and W. Weigel (1997), Increase of seismic velocities in upper oceanic crust: The "superfast" spreading East Pacific Rise, Geophys. Res. Lett., 24(3), 217-220, doi:10.1029/96GL04005.

Harding, A., J. Orcutt, M. Kappus, E. Vera, J. Mutter, R. Buhl, R. Detrick, and T. Brocher (1989), Structure of young oceanic crust at $13^{\circ} \mathrm{N}$ on the East Pacific Rise from expanding spread profile, J. Geophys. Res., 94(B9), 12,163-12,196, doi:10.1029/JB094iB09p12163. 
Harding, A. J., G. M. Kent, and J. A. Orcutt (1993), A multichannel seismic investigation of upper crustal structure at $9^{\circ} \mathrm{N}$ on the East Pacific Rise: Implications for crustal accretion, J. Geophys. Res., 98(B8), 13,92513,944, doi:10.1029/93JB00886.

Herron, T. (1982), Lava flow layer-East Pacific Rise, Geophys. Res. Lett., 9(1), 17-20, doi:10.1029/GL009i001p00017.

Hobro, J., S. Singh, and T. Minshull (2003), Three-dimensional tomographic inversion of combined reflection and refraction seismic traveltime data, Geophys. J. Int., 152, 79-93, doi:10.1046/j.1365-246X.2003.01822.x.

Hooft, E., R. Detrick, D. Toomey, J. Collins, and J. Lin (2000), Crustal thickness and structure along three contrasting spreading segments of

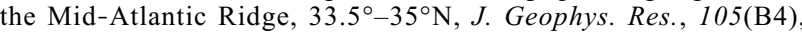
8205-8226, doi:10.1029/1999JB900442.

Houtz, R. (1976), Seismic properties of layer 2A in the Pacific, J. Geophys Res., 81(35), 6321-6331, doi:10.1029/JB081i035p06321.

Houtz, R., and E. Ewing (1976), Upper crustal structure as a function of plate age, J. Geophys. Res., 81(14), 2490-2498, doi:10.1029/JB081i014p02490.

Humphris, S., D. Fornari, D. Scheirer, C. German, and L. Parson (2002) Geotectonic setting of hydrothermal activity on the summit of Lucky Strike seamount $\left(37^{\circ} 17^{\prime} \mathrm{N}\right.$, Mid-Atlantic Ridge), Geochem. Geophys. Geosyst., 3(8), 1049, doi:10.1029/2001GC000284

Hussenoeder, S. A., R. S. Detrick, G. M. Kent, H. Schouten, and A. J. Harding (2002a), Fine-scale seismic structure of young upper crust at $17^{\circ} 20^{\prime} \mathrm{S}$ on the fast spreading East Pacific Rise, J. Geophys. Res. 107(B8), 2158, doi:10.1029/2001JB001688.

Hussenoeder, S. A., G. M. Kent, and R. S. Detrick (2002b), Upper crustal seismic structure of the slow spreading Mid-Atlantic Ridge, $35^{\circ} \mathrm{N}$ : Constraints on volcanic emplacement processes, J. Geophys. Res., 107(B8), 2156, doi:10.1029/2001JB001691.

Jacobs, A. M., A. Harding, and G. Kent (2007), Axial crustal structure of the Lau back-arc basin from velocity modeling of multichannel seismic data Earth Planet. Sci. Lett., 259, 239-255, doi:10.1016/j.eps1.2007.04.021.

Jacobson, R. (1992), Impact of crustal evolution on changes of the seismic properties of the uppermost ocean crust, Rev. Geophys., 30(1), 23-42, doi:10.1029/91RG02811.

Karson, J., and H. Dick (1983), Tectonics of ridge-transform intersections at the Kane fracture zone, Mar. Geophys. Res., 6, 51-98, doi:10.1007/ BF00300398.

Karson, J. A., et al. (2002), Structure of uppermost fast-spread oceanic crust exposed at the Hess Deep Rift: Implications for subaxial processes at the East Pacific Rise, Geochem. Geophys. Geosyst., 3(1), 1002, doi:10.1029/2001GC000155.

Klinkby, L., and M. Pedersen (1998), Attenuation of near-surface diffracted energy in deep seismic data by DMO correction, Tectonophysics, 286, 155-159, doi:10.1016/S0040-1951(97)00261-8.

Langmuir, C., et al. (1997), Hydrothermal vents near a mantle hot spot: The Lucky Strike vent field at $37^{\circ} \mathrm{N}$ on the Mid-Atlantic Ridge, Earth Planet Sci. Lett., 148, 69-91, doi:10.1016/S0012-821X(97)00027-7.

Liner, C. (1990), General theory and comparative anatomy of dip moveout, Geophysics, 55(5), 595-607, doi:10.1190/1.1442871.

Marques, A., F. Barriga, and S. Scott (2007), Sulfide mineralization in an ultramafic-rock hosted seafloor hydrothermal system: From serpentinization to the formation of $\mathrm{Cu}-\mathrm{Zn}$-(Co)-rich massive sulfides, Mar. Geol., 245, 20-39, doi:10.1016/j.margeo.2007.05.007.

McDonald, M., S. Webb, J. Hildebrand, and B. Cornuelle (1994), Seismic structure and anisotropy of the Juan de Fuca Ridge at $45^{\circ} \mathrm{N}, J$. Geophys Res., 99(B3), 4857-4873, doi:10.1029/93JB02801.

Minshull, T. A., N. J. Bruguier, and J. M. Brozena (2003), Seismic structure of the Mid-Atlantic Ridge, 8-9 ${ }^{\circ} \mathrm{S}$, J. Geophys. Res., 108(B11), 2513, doi:10.1029/2002JB002360.

Miranda, J., J. Luis, N. Lourenço, and F. Santos (2005), Identification of the magnetization low of the Lucky Strike hydrothermal vent using surface magnetic data, J. Geophys. Res., 110, B04103, doi:10.1029/ 2004JB003085

Müller, R., W. Roest, J.-Y. Royer, L. Gahagan, and J. Sclater (1997), Digital isochrons of the world's ocean floor, J. Geophys. Res., 102(B2), 3211-3214, doi:10.1029/96JB01781

Navin, D., C. Peirce, and M. Sinha (1998), The RAMESSES experimentII. Evidence for accumulated melt beneath a slow spreading ridge from wide-angle refraction and multichannel reflection seismic profiles, Geophys. J. Int., 135, 746-772, doi:10.1046/j.1365-246X.1998.00709.x.

Nedimović, M., S. Carbotte, J. Diebold, A. Harding, J. Canales, and G. Kent (2008), Upper crustal evolution across the Juan de Fuca ridge flanks, Geochem. Geophys. Geosyst., 9, Q09006, doi:10.1029/2008GC002085.

Nicolas, A., and F. Boudier (1995), Mapping oceanic ridge segments in Oman ophiolite, J. Geophys. Res., 100(B4), 6179-6197, doi:10.1029/ 94JB01188.
Nicolas, A., I. Reuber, and K. Benn (1988), A new magma chamber model based on structural studies in the Oman ophiolite, Tectonophysics, 151, 87-105, doi:10.1016/0040-1951(88)90242-9.

Notfors, C., and R. Godfrey (1987), Dip moveout in the frequency-wavenumber domain, Geophysics, 52(12), 1718-1721, doi:10.1190/ 1.1442289 .

Ondréas, H., M. Cannat, Y. Fouquet, A. Normand, P. Sarradin, and J. Sarrazin (2009), Recent volcanic events and the distribution of hydrothermal venting at the Lucky Strike hydrothermal field, Mid-Atlantic Ridge, Geochem Geophys. Geosyst., 10, Q02006, doi:10.1029/2008GC002171.

Parson, L., E. Gràcia, D. Coller, C. German, and D. Needham (2000), Second-order segmentation; the relationship between volcanism and tectonism at the MAR, $38^{\circ} \mathrm{N}-35^{\circ} 40^{\prime} \mathrm{N}$, Earth Planet. Sci. Lett., 178 , 231-251, doi:10.1016/S0012-821X(00)00090-X.

Peirce, C., M. Sinha, S. Topping, and C. Gill (2007), Morphology and genesis of slow-spreading ridges-seabed scattering and seismic imaging with the oceanic crust, Geophys. J. Int., 168, 59-89, doi:10.1111/j.1365246X.2006.03223.x.

Porsani, M. (1999), Seismic trace interpolation using half-step prediction filters, Geophysics, 64(5), 1461-1467, doi:10.1190/1.1444650.

Ranero, C., and T. Reston (1999), Detachment faulting at ocean core complexes, Geology, 27(11), 983-986, doi:10.1130/0091-7613(1999) 027<0983:DFAOCC $>2.3 . C O ; 2$.

Rohr, K., B. Milkereit, and C. Yorath (1988), Asymmetric deep crustal structure across the Juan de Fuca Ridge, Geology, 16, 533-537, doi:10.1130/0091-7613(1988)016<0533:ADCSAT>2.3.CO;2.

Schouten, H., M. Tivey, D. Fornari, and J. Cochran (1999), Central anomaly magnetization high: Constraints on the volcanic construction and architecture of seismic layer $2 \mathrm{~A}$ at a fast spreading mid-ocean ridge, the EPR at $9^{\circ} 30^{\prime}-50^{\prime} \mathrm{N}$, Earth Planet. Sci. Lett., 169, 37-50, doi:10.1016/S0012-821X(99)00063-1.

Schultz, P., and J. Claerbout (1978), Velocity estimation and downward continuation by wavefront synthesis, Geophysics, 43(4), 691-714, doi:10.1190/1.1440847.

Seher, T. (2008), Seismic structure of the Lucky Strike Segment at the MidAtlantic Ridge, Ph.D. thesis, Inst. de Phys. du Globe de Paris, Paris. Seher, T., W. C. Crawford, S. C. Singh, M. Cannat, V. Combier, and D. Dusunur (2010a), Crustal velocity structure of the Lucky Strike segment of the Mid-Atlantic Ridge at $37^{\circ} \mathrm{N}$ from seismic refraction measurements, J. Geophys. Res., 115, B03103, doi:10.1029/2009JB006650.

Seher, T., S. C. Singh, W. C. Crawford, and J. Escartín (2010b), Upper crustal velocity structure beneath the central Lucky Strike segment from seismic refraction measurements, Geochem. Geophys. Geosyst., 11, Q05001, doi:10.1029/2009GC002894

Severinghaus, J., and K. MacDonald (1988), High inside corners at ridgetransform intersections, Mar. Geophys. Res., 9(4), 353-367, doi:10.1007/ BF00315005.

Shaw, P. (1994), Age variations of oceanic crust Poisson's ratio: Inversion and a porosity evolution model, J. Geophys. Res., 99(B2), 3057-3066, doi:10.1029/93JB02109.

Singh, S., W. Crawford, H. Carton, T. Seher, V. Combier, M. Cannat, J. Canales, D. Düsünür, J. Escartin, and J. Miranda (2006), Discovery of a magma chamber and faults beneath a Mid-Atlantic Ridge hydrothermal field, Nature, 442, 1029-1032, doi:10.1038/nature05105.

Sohn, R., S. Webb, J. Hildebrand, and B. Cornuelle (1997), Threedimensional tomographic velocity structure of upper crust, coaxial segment, Juan de Fuca Ridge: Implications for on-axis evolution and hydrothermal circulation, J. Geophys. Res., 102(B8), 17,679-17,695, doi:10.1029/97JB00592.

Spitz, S. (1991), Seismic trace interpolation in the F-X domain, Geophysics, 56(6), 785-794, doi:10.1190/1.1443096.

Spudich, P., and J. Orcutt (1980), A new look at the seismic velocity structure of the oceanic crust, Rev. Geophys. Space Phys., 18(3), 627-645, doi:10.1029/RG018i003p00627.

Stolt, R. (1978), Migration by Fourier transform, Geophysics, 43(1), 23-48, doi:10.1190/1.1440826.

Stolt, R., and A. Benson (1986), Seismic Migration: Theory and Practice, Handb. Geophys. Explor., vol. 5, Geophys. Press, London.

Van Ark, E., R. Detrick, J. Canales, S. Carbotte, A. Harding, G. Kent M. Nedimovic, W. Wilcock, J. Diebold, and J. Babcok (2007), Seismic structure of the Endeavour segment, Juan de Fuca Ridge: Correlations with seismicity and hydrothermal activity, J. Geophys. Res., 112, B02401, doi:10.1029/2005JB004210

Vera, E., J. Mutter, P. Buhl, J. Orcutt, A. Harding, M. Kappus, R. Detrick, and T. Brocher (1990), The structure of 0- to 0.2-m.y.-old oceanic crust at $9^{\circ} \mathrm{N}$ on the East Pacific Rise from expanded spread profiles, J. Geophys. Res., 95(B10), 15,529-15,556, doi:10.1029/JB095iB10p15529. 
Wilkens, R., G. Fryer, and J. Karsten (1991), Evolution of porosity and seismic structure of upper oceanic crust: Importance of aspect ratios, J. Geophys. Res., 96(B11), 17,981-17,995, doi:10.1029/91JB01454.

Wright, T., C. Ebinger, J. Biggs, A. Ayele, G. Yirgu, D. Keir, and A. Stork (2006), Magma-maintained rift segmentation at continental rupture in the 2005 Afar dyking episode, Nature, 442, 291-294, doi:10.1038/ nature 04978.
Yilmaz, O. (1987), Seismic Data Processing, Invest. Geophys., vol. 2, Soc. of Explor. Geophys., Tulsa, Okla.

M. Cannat, W. C. Crawford, and S. C. Singh, Institut de Physique du Globe de Paris, Géosciences Marines, Boite 89, 4 pl. Jussieu, F-75252 Paris CEDEX 05, France.

T. Seher, EAPS-ERL, Massachusetts Institute of Technology, 77 Massachusetts Ave., 54-511, Cambridge, MA 02139-4307, USA. (seher@mit.edu) 